\title{
EXPOSURE TO PHTHALATES: REPRODUCTIVE OUTCOME AND CHILDREN HEALTH. A REVIEW OF EPIDEMIOLOGICAL STUDIES
}

\author{
JOANNA JUREWICZ and WOJCIECH HANKE \\ Nofer Institute of Occupational Medicine, Łódź, Poland \\ Department of Environmental Epidemiology
}

\begin{abstract}
Phthalates are a family of industrial chemicals that have been used for a variety of purposes. As the potential consequences of human exposure to phthalates have raised concerns in the general population, they have been studied in susceptible subjects such as pregnant women, infants and children. This article aims at evaluating the impact of exposure to phthalates on reproductive outcomes and children health by reviewing most recent published literature. Epidemiological studies focusing on exposure to phthalates and pregnancy outcome, genital development, semen quality, precocious puberty, thyroid function, respiratory symptoms and neurodevelopment in children for the last ten years were identified by a search of the PubMed, Medline, Ebsco, Agricola and Toxnet literature bases. The results from the presented studies suggest that there are strong and rather consistent indications that phthalates increase the risk of allergy and asthma and have an adverse impact on children's neurodevelopment reflected by quality of alertness among girls, decreased (less masculine) composite score in boys and attention deficit hyperactivity disorder. Results of few studies demonstrate negative associations between phthalate levels commonly experienced by the public and impaired sperm quality (concentration, morphology, motility). Phthalates negatively impact also on gestational age and head circumference; however, the results of the studies were not consistent. In all the reviewed studies, exposure to phthalates adversely affected the level of reproductive hormones (luteinizing hormone, free testosterone, sex hormone-binding globulin), anogenital distance and thyroid function. The urinary levels of phthalates were significantly higher in the pubertal gynecomastia group, in serum in girls with premature thelarche and in girls with precocious puberty. Epidemiological studies, in spite of their limitations, suggest that phthalates may affect reproductive outcome and children health. Considering the suggested health effects, more epidemiologic data is urgently needed and, in the meantime, precautionary policies must be implemented.
\end{abstract}

Key words:

Exposure to phthalates, Children health, Reproductive outcome

\section{INTRODUCTION}

Phthalates are suspected of being endocrine disrupting chemicals (EDCs). Endocrine disrupting substances may interfere with the production, secretion, transportation, metabolism, receptor binding, mediation of effects, and excretion of natural hormones which regulate developmental processes and support endocrine homeostasis in the organism [1].

Phthalates are a family of industrial chemicals that have been used for a variety of purposes. They are added to plastics including children's toys and medical devices to make them soft and flexible as well as to cosmetics as a vehicle

This study was performed under the project "Prenatal and postnatal exposure to tobacco smoke, PAHs and heavy metals and the risk of respiratory diseases, allergy and poor mental and physical development" supported by the grant PNRF-218-AI-1/07 from Norway through the Norwegian Financial Mechanism within the PolishNorwegian Research Fund.

Received: March 16, 2011. Accepted: April 11, 2011.

Address reprint request to J. Jurewicz, Department of Environmental Epidemiology, Nofer Institute of Occupational Medicine, św. Teresy 8, 91-348 Łódź, Poland (e-mail: joannaj@imp.lodz.pl). 
for fragrance. Phthalates can also be found in adhesives and glues, agricultural adjuvants, building materials, personal care products, detergents, paints, pharmaceuticals, food products and textiles. They are also used in a variety of household applications such as shower curtains, vinyl upholstery, floor tiles, food containers and wrappers, and cleaning materials. The most widely used phthalates are the di-(2-ethylhexyl) phthalate (DEHP), the diisodecyl phthalate (DIDP), and the diisononyl phthalate (DINP). DEHP is the dominant plasticizer used in PVC due to its low cost. Another phthalate, benzylbutylphthalate (BBP) is used in the manufacture of foamed PVC-popular flooring material. Because phthalates are ubiquitous in daily life, the potential consequences of human exposure to phthalates have raised concerns in the general population and have been studied in susceptible subjects such as pregnant women, infants and children [2].

DEHP induced anti-androgenic action and abnormalities of the male reproductive system in prenatally exposed animals, likely affecting the normal development of the testes [3-7]. Consequently, most of the research on phthalates is focused on their association with aberrant male reproductive development [8]. Some phthalates, notably DEHP and dibutyl phthalate (DBP), inhibit the synthesis of testosterone by Leydig cells, thereby reducing fetal testosterone concentration in experimental studies [9]. This caused disordered sex differentiation, including a reduced anogenital distance (AGD), impaired testicular descent and reduced genital size [10]. Extensive experimental research on reproductive effects of phthalates has been published indicating lower birth weight or early body weight in rodents after prenatal exposure to various phthalates [11-13]. Studies on humans demonstrated decreased sperm quality [14-16] and negative effects on children's health [17], including reduced birth weight [18] and impaired development of the reproductive system [19]. Evidence regarding EDCs and their importance in the synthesis of selected cytokines, immunoglobulins, and cell mediators as well as their impact on immune cell activation and survival has recently been presented by Chalubinski and Kowalski [20]. Phthalates have also been suggested to act as either allergens or adjuvants [21,22] and cause allergy and asthma [23,24].

Although phthalates do not bioaccumulate in the body like dioxins and other chemicals, their ubiquitous presence in the environment and the size of the population exposed suggest that the potential impact of phthalate exposure could be very large. Humans are exposed to phthalates by multiple routes. Exposures can be oral (e.g., DEHP via phthalate-contaminated food, water and other liquids, in children through mouthing of toys and tethers) or dermal (e.g., diethyl phthalate (DEP), via cosmetics and other personal care products). Exposure can also be via inhalation (phthalates volatilize from PVC, nail polish, hair spray, and other phthalate-containing products) and parenteral (e.g., DEHP via tubing used in neonatal intensive care nurseries). Because phthalates can cross the placenta, exposure to the developing fetus during critical points in development is also a concern. Fetuses may have been exposed to phthalates and their monoesters in the amniotic fluid of their mothers [25]. Once absorbed, phthalates are rapidly metabolized to the high-molecular-weight monoesters, which can undergo further oxidation to form oxidative metabolites [26]. Phthalate metabolites have been detected in many body tissues including urine, blood, semen, amniotic fluid and breast milk [26]. Phthalates have also been measured in residential indoor environments in both house dust [24,27] and indoor air [28] as well as in foods, milk, and drinking water. However, the relative contribution from the various sources and routes of exposure to phthalates is unknown [29].

As there is increasing evidence that exposure to phthalates may affect human health, the aim of this paper is to critically review the literature on exposure to phthalates, reproductive outcome and children health. 


\section{MATERIALS AND METHODS}

Epidemiological studies focused on the exposure to phthalates and reproductive outcome or children health were identified by a search of the PubMed, Medline, Ebsco, Agricola and Toxnet literature databases. The combination of key words used were: exposure to phthalates, reproductive disorders, pregnancy outcome, semen quality, endocrine disruptors, respiratory symptoms, children's neurodevelopment, precocious puberty. From each study, the following information was abstracted: study population, type of outcome (pregnancy outcome, semen quality, neurodevelopment, respiratory symptoms, precocious puberty), exposure and methods used for its assessment (including biomarkers). Finally, in this review were included human studies published in English in peer reviewed journals since 2000. The period was chosen because there were few studies conducted on human health outcomes associated with phthalate exposure prior to 2000. At that time the availability of sensitive, specific, and affordable bioassays made biomarkers feasible for the use in epidemiological studies for measuring exposures to phthalates. At the same time, growing rodent literature provided convincing data on the reproductive toxicity of several commonly used phthalates [39].

\section{RESULTS}

\section{Reproductive outcomes}

Animal studies have showed that exposure to phthalates results in profound and irreversible changes in the development of reproductive tract $[4,31]$ especially in males, raising the possibility that phthalate exposures could be the leading cause of the reproductive disorders in humans [32,33].

Many adverse effects on animal fertility and reproduction have been documented for phthalates following exposure before puberty. In particular, certain phthalates (DEHP, DBP, BBP) when administered to pregnant experimental animals during a critical window of development appear to play a relevant role in determining

Table 1. Exposure to phthalates and reproductive outcome

\begin{tabular}{|c|c|c|c|c|}
\hline Study population & $\begin{array}{c}\text { Type } \\
\text { of study }\end{array}$ & Definition of exposure & Results & References \\
\hline $\begin{array}{l}\text { US, New York City } \\
404 \text { women }\end{array}$ & $\begin{array}{l}\text { Cohort } \\
\text { study }\end{array}$ & $\begin{array}{l}\text { Urine }-5 \text { phenol } \\
(2,5-D C P, 2,4-D C P, \\
\text { TCS, BP3, BPA) and } 10 \\
\text { (MECPP, MEHHP, } \\
\text { MEOHP, MEHP, MBzP, } \\
\text { MCPP, MiBP, MBP, } \\
\text { MEP, MMP) phthalate } \\
\text { metabolites (measured } \\
\text { in the third trimester } \\
\text { of pregnancy) }\end{array}$ & $\begin{array}{l}\text { Low-molecular-weight phthalate } \\
\text { monoesters (low-MWP) metabolites had } \\
\text { a positive association with: } \\
\text { gestational age: } 0.97 \text { ( } 95 \% \text { CI: } 0.07-1.9) \text {, } \\
\text { head circumference: } 0.13 \text { ( } 95 \% \text { CI: } \\
0.01-0.24) \text {. } \\
\text { Higher prenatal exposure } \\
\text { to } 2,5 \text {-dichlorphenol ( } 2,5 \text {-DCP) predicted } \\
\text { lower birth weight in boys ( }-210 \mathrm{~g} \text { average } \\
\text { birth weight) }\end{array}$ & Wolff 2008 [18] \\
\hline $\begin{array}{l}\text { Denmark } \\
130 \text { infants; } \\
62 \text { cryptorchid } \\
\text { / } 68 \text { healthy boys }\end{array}$ & $\begin{array}{l}\text { Cohort } \\
\text { study }\end{array}$ & $\begin{array}{l}\text { Breast milk collected } \\
1-3 \text { months postnatally } \\
\text { was analyzed } \\
\text { for } 6 \text { phthalate } \\
\text { monoesters (MMP, MEP, } \\
\text { MBP, MBzP, MEHP, } \\
\text { MiNP) }\end{array}$ & $\begin{array}{l}\text { MEP and MBP were positively correlated } \\
\text { with sex-hormone binding globin (SHBG) } \\
(p=0.002 \text { and } p=0.01 \text {, respectively); } \\
\text { MMP, MEP, and MBP with the ratio of } \\
\text { LH to free testosterone }(p=0.002-0.044) \\
\text { and MiNP with luteinizing hormone } \\
(p=0.019) . \text { MBP was negatively correlated } \\
\text { with free testosterone }(p=0.033) \text {. }\end{array}$ & Mein 2006 [47] \\
\hline
\end{tabular}


Table 1. Exposure to phthalates and reproductive outcome - cont.

\begin{tabular}{|c|c|c|c|c|}
\hline Study population & $\begin{array}{c}\text { Type } \\
\text { of study }\end{array}$ & Definition of exposure & Results & References \\
\hline $\begin{array}{l}\text { Italy, } \\
84 \text { newborns }\end{array}$ & $\begin{array}{l}\text { Cross- } \\
\text { sectional }\end{array}$ & $\begin{array}{l}\text { Serum DEHP and MEHP } \\
\text { concentrations in the cord } \\
\text { blood of } 84 \text { consecutive } \\
\text { newborns }\end{array}$ & $\begin{array}{l}\text { MEHP-positive newborns showed } \\
\text { a significantly lower gestational } \\
\text { age compared with MEHP-negative } \\
\text { infants }(\mathrm{p}=0.033) \text {. Logistic regression } \\
\text { analysis results indicated a positive } \\
\text { correlation between absence } \\
\text { of MEHP in cord blood and gestational } \\
\text { age at delivery } \\
(\mathrm{OR}=1.50 ; 95 \% \text { CI: } 1.013-2.21 \text {; } \\
\mathrm{p}=0.043) \text {. }\end{array}$ & Latini 2003 [36] \\
\hline
\end{tabular}

2,5-DCP - 2,5-dichlorophenol; 2,4-DCP - 2,4-dichlorophenol; BP3 - benzophenone-3; TCS - triclosan; BAP - bisphenol A; MCPP - mono-3-carboxypropyl phthalate; MEHHP - mono-(2-ethyl-5-hydroxylhexyl) phthalate; MEOHP - mono-(2-ethyl-5-oxohexyl) phthalate; MiBP - monoisobutyl phthalate; MEP - monoethyl phthalate; MBzP - monobenzyl phthalate; MBP - monobutyl phthalate; MECPP - mono-2-ethyl-5-carboxypentyl phthalate; MEHP - mono-(2-ethylhexyl) phthalate; MMP - monomethyl phtalate; MinP - monoisononyl phthalate; DEHP — di-(2-ethylhexyl) phthalate.

Table 2. Exposure to phthalates and genital development

\begin{tabular}{|c|c|c|c|c|}
\hline Study population & $\begin{array}{l}\text { Type of } \\
\text { study }\end{array}$ & Definition of exposure & Results & References \\
\hline $\begin{array}{l}\text { Taiwan, } \\
65 \text { pregnant women }\end{array}$ & $\begin{array}{l}\text { Cohort } \\
\text { study }\end{array}$ & $\begin{array}{l}\text { Amniotic fluid and urine } \\
\text { samples from pregnant } \\
\text { women were collected } \\
\text { to measure } 5 \text { phthalate } \\
\text { monoesters (MBP, MEHP, } \\
\text { MEP, MBzP, MMP) }\end{array}$ & $\begin{array}{l}\text { Significant positive correlation } \\
\text { only between creatinine adjusted } \\
\text { urinary MBP and amniotic fluid } \\
\text { MBP }(p<0.05) \text { in all infants and, } \\
\text { only in female infants, a significantly } \\
\text { negative correlation between amniotic } \\
\text { fluid MBP, AGD }(p<0.06) \text {, and the } \\
\text { anogenital index adjusted by birth weight } \\
(p<0.05)\end{array}$ & Huang 2009 [54] \\
\hline $\begin{array}{l}\text { Mexico, } \\
73 \text { pregnant women }\end{array}$ & $\begin{array}{l}\text { Hospital- } \\
\text { based } \\
\text { cohort }\end{array}$ & $\begin{array}{l}\text { Phthalate monoester } \\
\text { metabolites, measured } \\
\text { in prenatal urine samples } \\
\text { (MEHP, MBzP, MEP, } \\
\text { MBP) }\end{array}$ & $\begin{array}{l}\text { Statistically significant association } \\
\text { between MEP exposure and reduced } \\
\text { AGD and also between MBzP exposure } \\
\text { and reduced penis length and width }\end{array}$ & $\begin{array}{l}\text { Bustamante- } \\
\text { Montes } 2008 \text { [53] }\end{array}$ \\
\hline $\begin{array}{l}\text { United States } \\
\text { Clinics affiliated with } \\
\text { university hospitals } \\
\text { in Los Angeles, } \\
\text { Minneapolis, Columbia } \\
\text { and in Iowa City; } \\
134 \text { boys 2-36 months } \\
\text { of age }\end{array}$ & $\begin{array}{l}\text { Multicenter } \\
\text { cohort study }\end{array}$ & $\begin{array}{l}9 \text { phthalate monoester } \\
\text { metabolites, measured } \\
\text { in prenatal urine } \\
\text { samples (MBP, MBzP, } \\
\text { MCPP, MEP, MiBP, } \\
\text { MMP, MEHHP, MEHP, } \\
\text { MEOHP) }\end{array}$ & $\begin{array}{l}\text { Significant associations between AGD } \\
\text { and the three metabolites of DEHP: } \\
\text { MEHHP, MEHP, MEOHP, as well } \\
\text { as their sum } \\
\text { Relationship between DEHP metabolites } \\
\text { and penile width. MEHP metabolite was } \\
\text { significantly and inversely related } \\
\text { to testicular descent. }\end{array}$ & Swan 2008 [52] \\
\hline
\end{tabular}


Table 2. Exposure to phthalates and genital development - cont.

\begin{tabular}{|c|c|c|c|c|}
\hline Study population & $\begin{array}{l}\text { Type of } \\
\text { study }\end{array}$ & Definition of exposure & Results & References \\
\hline $\begin{array}{l}\text { United States, } \\
\text { Clinics affiliated with } \\
\text { university hospitals } \\
\text { in Los Angeles, } \\
\text { Minneapolis, Columbia } \\
\text { and in Iowa City; } \\
85 \text { boys } 2-36 \text { months } \\
\text { of age }\end{array}$ & $\begin{array}{l}\text { Multicenter } \\
\text { cohort study }\end{array}$ & $\begin{array}{l}9 \text { phthalate monoester } \\
\text { metabolites, measured } \\
\text { in prenatal urine } \\
\text { samples (MBP, MBzP, } \\
\text { MCPP, MEP, MiBP, } \\
\text { MMP, MEHHP, MEHP, } \\
\text { MEOHP) }\end{array}$ & $\begin{array}{l}\text { Urinary concentrations of MEP, MBP, } \\
\text { MBzP, MiBP were inversely related to } \\
\text { anogenital index (AGI) } \\
\text { Comparing boys with prenatal MBP } \\
\text { concentration in the highest quartile with } \\
\text { those in the lowest quartile, the odds ratio } \\
\text { for a shorter than expected AGI was } 10.2 \\
\text { (95\% CI: } 2.5-42.2) \text {. The corresponding } \\
\text { odds ratios for MEP, MBzP, and MiBP } \\
\text { were 4.7, 3.8, and 9.1, respectively } \\
\text { (all p-values }<0.05 \text { ) }\end{array}$ & Swan 2005 [8] \\
\hline
\end{tabular}

AGI — anogential index; AGD — anogenital distance/weight.

Other abbreviations as in Table 1.

reproductive and developmental toxicity [34]. These esters have been shown to produce a syndrome of reproductive abnormalities - the phthalate syndrome, characterized by malformations of the epididymis, vas deferens, seminal vesicles, prostate, external genitalia (hypospadias), cryptorchidism [10]. On other hand, only a limited number of studies in human populations suggest an association between phthalate exposure and adverse reproductive health outcomes [35]. A correlation was found between urinary phthalate levels and pregnancy complications such as anemia, toxemia, and preeclampsia in women living near a plastics manufacturer [36,37]. The results of the studies on exposure to phthalates and reproductive outcome in humans are presented in Table 1 and their impact on genital development in Table 2.

\section{Body size measures of the infants at birth}

The study evaluating the association between prenatal exposures to phthalates and phenol metabolites on body size measures of the infants at birth was performed among a cohort of pregnant New York City women. Concentrations of low-molecular-weight phthalate monoesters (low-MWP) (which can be found in personal care products like fragrances, shampoo, cosmetics, and nail polish) were positively associated with gestational age and with head circumference in boys and girls [18]. Higher prenatal exposures to 2,5-dichlorophenol (2,5-DCP) predicted lower birth weight in boys ( $-210 \mathrm{~g}$ average birth weight difference between the third tertile and first tertile of 2,5-DCP exposure) [18]. The phthalate exposure was also associated with a shorter pregnancy duration in the study performed by Latini and co-workers (2003) [25]. The authors measured serum DEHP and mono-(2-ethylhexyl) phthalate (MEHP) in the cord blood of 84 infants born in Italy. Infants for whom MEHP and DEHP were detectable in cord blood were categorized as "MEHP-positive" and "DEHP-positive". MEHP-positive newborns showed a significantly lower gestational age compared with MEHP-negative infants. No associations with gestational age were found for DEHP, and no significant relations were observed between either DEHP or MEHP and birth weight [25].

\section{Reproductive hormones and cryptorchidism}

The one study showing an association between phthalate exposure and reproductive hormones in boys was performed in Denmark [38]. Both mono-ethyl phthalate (MEP) and mono- $n$-butyl phthalate (MBP) showed significant positive correlations with sex hormone-binding 
globulin (SHBG). Mono-methyl phthalate (MMP), MEP, and MBP were significantly positively correlated with the luteinizing hormone ( $\mathrm{LH})$ /free testosterone ratio, while mono-isononyl phthalate (MiNP) was positively correlated with increasing level of LH. MBP was negatively correlated with free testosterone. However, no association was found between phthalate monoester levels and cryptorchidism in boys in that study [38].

\section{Anogenital distance}

Anogenital distance (AGD) is an indicator of in utero androgenic exposure [39] and has been added to the US EPA testing guidelines for reproductive toxicity studies [40-42]. The first study which examined AGD in relation to prenatal phthalate exposure in humans was performed in four cities in United States (Los Angeles, Minneapolis, Columbia, Iowa City) in a multicenter pregnancy cohort study (85 boys) [8]. Anogenital index (AGI) was defined as AGD divided by weight at examination $[\mathrm{AGI}=\mathrm{AGD} /$ weight $(\mathrm{mm} / \mathrm{kg})]$ and the age-adjusted AGI was calculated by regression analysis. Urinary concentrations of four phthalate metabolites: MEP, MBP, monobenzyl phthalate (MBzP), and monoisobutyl phthalate (MiBP) were inversely related to AGI ( $p$-values for regression coefficients ranged from 0.007 to 0.097). Comparison was done between boys with prenatal MBP concentration in the highest quartile and those in the lowest quartile. The odds ratio for a shorter than expected AGI was 10.2, 95\% CI: 2.5-42.2. The corresponding odds ratios for MEP, MBzP, and MiBP were 4.7, 3.8, and 9.1, respectively (all p-values < 0.05). This data supports the hypothesis that prenatal phthalate exposure at environmental levels can adversely affect male reproductive development in humans [8]. This study was updated by Swan in 2008 [43] by including a bigger sample size (106 boys) and analysing examined DEHP metabolite concentrations in relation to both AGD and two other endpoints consistent with the phthalate syndrome (e.g., penile width and testicular descent). In the updated analysis, significant associations between decrease of AGD and the three metabolites of DEHP, 5 mono(2-ethylhexyl) phthalate (MEHHP), MEHP, 5 oxo-mono-(2-ethylhexyl) phthalate (MEOHP)), as well as their sum were found. Relationships between DEHP metabolites (most notably MEHP) and penile width were observed as well [43].

Another study of 73 pregnant Mexican women in a hospital-based cohort investigated the association between exposure to MEHP, MBzP, MEP and MBP during pregnancy and AGD in male newborns. This study found a statistically significant association between MEP exposure and reduced $\mathrm{AGD}$ and also between $\mathrm{MBzP}$ exposure and reduced penis length and width [44].

In the study performed in Taiwan, amniotic fluid and urine samples from 65 pregnant women were collected to measure five phthalate monoesters (MBP, MEHP, MEP, $\mathrm{MBzP}$ and mono-methyl phthalate (MMP)). A borderline significantly negative correlation was found in female infants between amniotic fluid MBP and AGD $(\mathrm{p}<0.06)$ as well as the anogenital index adjusted by birth weight $(\mathrm{p}<0.05)$. However, no correlation was found between prenatal phthahlate exposure in utero and AGI in male newborns [45].

Summing up: the effects of phthalates exposure on pregnancy outcome in humans are by no means consistent. While some phthalates (DEHP and metabolite MEHP) seem to be negatively associated with gestational age [25], others, like the sum of low and high molecular weight phthalate monoesters (low MWP and high MWP) exposure, had shown a positive association with gestational age and with head circumference [18].

Reproductive hormones seem to be affected by the exposure to phthalates. MMP, MEP, and MBP were significantly positively correlated with the luteinizing hormone (LH)/free testosterone ratio and MiNP with increasing level of LH. Similarly, MBP was negatively correlated with free testosterone [38]. Phthalate exposure (MEP, MBP, MBzP, MiBP, MEHP, MEOHP, MEHHP) also was 
associated with reduced anogenital distance [8,43-45]. On the other hand, no association was found between phthalate monoester levels and cryptorchidism [38], which is consisted with animal studies.

\section{Semen quality, sperm DNA damage and male reproductive hormones}

Laboratory experiments with rodents have shown that phthalates can adversely affect sperm quality. Ge et al. [46] found that at lower doses phthalates increase testosterone production either by increasing Leyding cell numbers or by directly stimulating testosterone production [46]. However, inhibition of testosterone was noticed in both fetal and adult Leyding cells when rats were exposed to higher doses [46]. Other studies in animals showed reduction of protein levels in fetal Leyding cells and deregulation of cholesterol transport and steroid synthesis [47].

Several recent epidemiological studies have addressed the male reproductive toxicity of phthalates [14,15, 48-52] (Table 3). Duty et al. [48], in Boston compared levels of eight phthalate metabolites in urine among men with normal and abnormal semen quality recruited from 168 subfertile couples. They observed an inverse dose-response relationship between two phthalate metabolites (MBP, MBzP) and both sperm concentration and motility. These findings were corroborated

Table 3. Exposure to phthalates and semen quality

\begin{tabular}{|c|c|c|c|c|c|}
\hline Study population & $\begin{array}{l}\text { Type of } \\
\text { study }\end{array}$ & $\begin{array}{l}\text { Definition of } \\
\text { exposure }\end{array}$ & Semen analysis & Results & References \\
\hline $\begin{array}{l}\text { United States } \\
\text { Male partners } \\
(\mathrm{N}=45) \text { of } \\
\text { subfertile couples } \\
\text { presenting } \\
\text { to a Michigan } \\
\text { infertility clinic }\end{array}$ & $\begin{array}{l}\text { Cross- } \\
\text { sectional } \\
\text { pilot } \\
\text { study }\end{array}$ & $\begin{array}{l}\text { Urinary } \\
\text { concentrations } \\
\text { of phthalate } \\
\text { metabolites: MEP, } \\
\text { DEHP, mono- } \\
\text { 3-carboxypropyl } \\
\text { phthalate }\end{array}$ & $\begin{array}{l}\text { Motility, } \\
\text { concentration } \\
\text { and morphology }\end{array}$ & $\begin{array}{l}\text { Low sperm concentration was } \\
\text { significantly associated with } \\
\text { above median concentrations of } \\
\text { MEP and low morphology with } \\
\text { above median concentrations } \\
\text { of mono-3-carboxypropyl } \\
\text { phthalate. Increased odds } \\
\text { for low concentration and } \\
\text { above median concentrations } \\
\text { of metabolites of DEHP } \\
\text { (OR = 5.4, 95\% CI: } 0.9-30.8) \\
\text { and low morphology and above } \\
\text { median concentrations of MEP } \\
\text { (OR = 3.4, 95\% CI: } 0.9-13.8) \\
\text { were also found }\end{array}$ & Wirth 2008 [59] \\
\hline $\begin{array}{l}\text { India } \\
\text { Urban/rural } \\
\text { population of } \\
\text { Lucknow visiting } \\
\text { Obstetrics and } \\
\text { Gynecology } \\
\text { Department }\end{array}$ & $\begin{array}{l}\text { Cross- } \\
\text { sectional }\end{array}$ & $\begin{array}{l}\text { Urinary } \\
\text { concentrations } \\
\text { of } 5 \text { phthalate esters } \\
\text { (DEP, DEHP, DBP, } \\
\text { DMP, DOP) }\end{array}$ & $\begin{array}{l}\text { Motility, } \\
\text { concentration } \\
\text { and morphology }\end{array}$ & $\begin{array}{l}\text { Infertile men showed } \\
\text { statistically significant } \\
(\mathrm{p}<0.05) \text { higher levels } \\
\text { of pollutants in the semen } \\
\text { than fertile men. A negative } \\
\text { correlation between semen } \\
\text { phthalate level viz DEHP and } \\
\text { sperm quality and positive } \\
\text { association with depolarized } \\
\text { mitochondria, elevation in ROS } \\
\text { production and LPO, DNA } \\
\text { fragmentation was established }\end{array}$ & Pant 2008 [60] \\
\hline
\end{tabular}


Table 3. Exposure to phthalates and semen quality — cont.

\begin{tabular}{|c|c|c|c|c|c|}
\hline Study population & $\begin{array}{l}\text { Type of } \\
\text { study }\end{array}$ & $\begin{array}{c}\text { Definition of } \\
\text { exposure }\end{array}$ & Semen analysis & Results & References \\
\hline $\begin{array}{l}\text { United States } \\
463 \text { male partners } \\
\text { of subfertile couples } \\
\text { who presented for } \\
\text { semen analysis to } \\
\text { the Massachusetts } \\
\text { General Hospital } \\
\text { between } \\
\text { January } 2000 \\
\text { and May } 2004\end{array}$ & $\begin{array}{l}\text { Cross- } \\
\text { sectional }\end{array}$ & $\begin{array}{l}\text { Phthalate metabolites } \\
\text { in urine were } \\
\text { measured (MEP, } \\
\text { MBP, MBzP, MMP, } \\
\text { MEHP, MEHHP, } \\
\text { MEOHP) }\end{array}$ & $\begin{array}{l}\text { Comet extent } \\
\text { (CE), percentage } \\
\text { of DNA in tail } \\
\text { (Tail\%) and } \\
\text { tail distributed } \\
\text { moment } \\
\text { (TDM) }\end{array}$ & $\begin{array}{l}\text { MEP was associated with } \\
\text { increased DNA damage. } \\
\text { MEHP was associated } \\
\text { with DNA damage after } \\
\text { adjustment for the oxidative } \\
\text { DEHP metabolites. After } \\
\text { adjustment for MEHHP, } \\
\text { for an interquartile range } \\
\text { increase in urinary MEHP, } \\
\text { CE increased 17.3\% (95\% CI: } \\
\text { 8.7-25.7), TDM increased } \\
\text { 14.3\% (95\% CI: 6.8-21.7) } \\
\text { and Tail\% increased 17.5\% } \\
\text { (95\% CI: } 3.5-31.5 \text { ) }\end{array}$ & Hauser 2007 [62] \\
\hline $\begin{array}{l}\text { China } \\
\text { Participants residing } \\
\text { in Shanghai were } \\
\text { surveyed in } 2002 . \\
\text { Semen samples } \\
\text { of } 52 \text { men (aged } \\
\text { from } 23 \text { to } 48 \text { years) } \\
\text { were collected } \\
\text { from outpatients of } \\
\text { Shanghai Institute of } \\
\text { Planned Parenthood } \\
\text { Research }\end{array}$ & $\begin{array}{l}\text { Cross- } \\
\text { sectional }\end{array}$ & $\begin{array}{l}\text { Concentrations } \\
\text { of three kinds of } \\
\text { commonly used } \\
\text { phthalates (DEP, } \\
\text { DBP, DEHP) }\end{array}$ & $\begin{array}{l}\text { Sperm density, } \\
\text { livability, } \\
\text { concentration }\end{array}$ & $\begin{array}{l}\text { There was a significant positive } \\
\text { association between liquefied } \\
\text { time of semen and phthalate } \\
\text { concentrations of semen. } \\
\text { There was no significant } \\
\text { difference between phthalate } \\
\text { concentrations of semen and } \\
\text { sperm density or livability }\end{array}$ & Zhang 2006 [61] \\
\hline $\begin{array}{l}\text { United States } \\
463 \text { male partners } \\
\text { of subfertile couples } \\
\text { who presented for } \\
\text { semen analysis to } \\
\text { the Massachusetts } \\
\text { General Hospital } \\
\text { between } \\
\text { January } 2000 \text { and } \\
\text { May } 2004\end{array}$ & $\begin{array}{l}\text { Cross- } \\
\text { sectional }\end{array}$ & $\begin{array}{l}\text { Phthalate metabolites } \\
\text { in urine were } \\
\text { measured (MEP, } \\
\text { MBP, MBzP) }\end{array}$ & $\begin{array}{l}\text { Sperm } \\
\text { concentration, } \\
\text { motility, } \\
\text { morphology }\end{array}$ & $\begin{array}{l}\text { There were dose-response } \\
\text { relationships of mono-butyl } \\
\text { phthalate MBP with low sperm } \\
\text { concentration and motility. } \\
\text { There was suggestive evidence } \\
\text { of an association between the } \\
\text { highest MBzP quartile and low } \\
\text { sperm concentration }\end{array}$ & Hauser 2006 [15] \\
\hline $\begin{array}{l}\text { United States } \\
295 \text { male partners } \\
\text { of subfertile couples } \\
\text { who presented for } \\
\text { semen analysis to } \\
\text { the Massachusetts } \\
\text { General Hospital } \\
\text { between } 1999 \\
\text { and } 2003\end{array}$ & $\begin{array}{l}\text { Cross- } \\
\text { sectional }\end{array}$ & $\begin{array}{l}5 \text { phthalate } \\
\text { metabolites were } \\
\text { measured in urine } \\
\text { (MBP, MEP, MBzP, } \\
\text { MEHP, MMP) }\end{array}$ & Sexual hormones & $\begin{array}{l}\text { An interquartile range (IQR) } \\
\text { change in MBzP exposure } \\
\text { was significantly associated } \\
\text { with a } 10 \% \text { decrease in FSH } \\
\text { concentration. An IQR } \\
\text { change in MBP exposure was } \\
\text { associated with a } 4.8 \% \text { increase } \\
\text { in inhibin B but this was of } \\
\text { borderline significance }\end{array}$ & Duty 2005 [14] \\
\hline
\end{tabular}


Table 3. Exposure to phthalates and semen quality — cont.

\begin{tabular}{|c|c|c|c|c|c|}
\hline Study population & $\begin{array}{c}\text { Type of } \\
\text { study }\end{array}$ & $\begin{array}{c}\text { Definition of } \\
\text { exposure }\end{array}$ & Semen analysis & Results & References \\
\hline $\begin{array}{l}\text { Sweden } \\
234 \text { young } \\
\text { Swedish men }\end{array}$ & $\begin{array}{l}\text { Cross- } \\
\text { sectional }\end{array}$ & $\begin{array}{l}\text { Urinary } \\
\text { concentrations of } 4 \\
\text { phthalate metabolites } \\
\text { (MEP, MEHP, MBzP, } \\
\text { MBP) }\end{array}$ & $\begin{array}{l}\text { Semen } \\
\text { volume, sperm } \\
\text { concentration } \\
\text { and motility were } \\
\text { measured, together } \\
\text { with sperm } \\
\text { chromatin integrity } \\
\text { (sperm chromatin } \\
\text { structure assay) } \\
\text { and biochemical } \\
\text { markers of } \\
\text { epididymal and } \\
\text { prostatic function, } \\
\text { reproductive } \\
\text { hormones in serum }\end{array}$ & $\begin{array}{l}\text { Subjects within the highest } \\
\text { quartile for MEP had fewer } \\
\text { motile sperms, more immotile } \\
\text { sperms, and lower luteinizing } \\
\text { hormone values, but there was } \\
\text { no suggestion of harmful effects } \\
\text { for most other endpoints }\end{array}$ & Jonsson 2005 [58] \\
\hline $\begin{array}{l}\text { United States } \\
168 \text { men from the } \\
\text { Massachusetts } \\
\text { General Hospital } \\
\text { Andrology } \\
\text { Laboratory }\end{array}$ & $\begin{array}{l}\text { Cross- } \\
\text { sectional }\end{array}$ & $\begin{array}{l}8 \text { phthalate } \\
\text { metabolites were } \\
\text { measured in urine } \\
\text { (MEP, MMP, MEHP, } \\
\text { MBP, MBzP, MOP, } \\
\text { MINP, MCHP) }\end{array}$ & $\begin{array}{l}\text { Comet extent - } \\
\text { a measure of total } \\
\text { comet length }(\mu \mathrm{m}) \text {, } \\
\text { percent DNA in } \\
\text { tail (tail\%) - } \\
\text { a measure of the } \\
\text { proportion of total } \\
\text { DNA present in } \\
\text { the comet tail, } \\
\text { tail distributed } \\
\text { moment (TDM) - } \\
\text { an integrated } \\
\text { measure of length } \\
\text { and intensity ( } \mu \mathrm{m})\end{array}$ & $\begin{array}{l}\text { With increased MEP level, } \\
\text { the comet extent increased } \\
\text { significantly by } 3.6 \mu \mathrm{m} \\
(95 \% \mathrm{CI}: 0.74-6.47) \text {; the TDM } \\
\text { also increased } 1.2 \mu \mathrm{m}(95 \% \mathrm{CI} \text { : } \\
-0.05-2.38) \mathrm{MBP}, \mathrm{MBzP}, \\
\text { MMP, and MEHP were not } \\
\text { significantly associated with } \\
\text { comet assay parameters }\end{array}$ & Duty 2003 [63] \\
\hline $\begin{array}{l}\text { United States } \\
168 \text { men who were } \\
\text { part of subfertile } \\
\text { couples and who } \\
\text { presented to the } \\
\text { Massachusetts } \\
\text { General Hospital } \\
\text { andrology } \\
\text { laboratory for semen } \\
\text { analysis between } \\
\text { January } 2000 \\
\text { and April } 2001\end{array}$ & $\begin{array}{l}\text { Cross- } \\
\text { sectional }\end{array}$ & $\begin{array}{l}8 \text { phthalate } \\
\text { metabolites were } \\
\text { measured in urine } \\
\text { (MEP, MMP, MEHP, } \\
\text { MBP, MBzP, MOP, } \\
\text { MINP, MCHP) }\end{array}$ & $\begin{array}{l}\text { Sperm } \\
\text { concentration, } \\
\text { motility, } \\
\text { morphology }\end{array}$ & $\begin{array}{l}\text { A dose-response relation } \\
\text { between tertiles of MBP } \\
\text { and sperm motility and } \\
\text { sperm concentration. } \\
\text { There was a dose-response } \\
\text { relation between tertiles of } \\
\text { MBzP phthalate and sperm } \\
\text { concentration }\end{array}$ & Duty 2003 [57] \\
\hline
\end{tabular}

DEP — diethyl phthalate; DBP — di-n-butyl phthalate; DEHP — di-(2-ethylhexyl) phthalate; DMP — dimethyl phthalate; DOP — di-octyl pthalate; MNIP - mono-3-methyl-5-dimethylhexyl (isononyl) phthalate; MCHP — monocyclohexyl phthalate.

Other abbreviations as in Table 1. 
in a subsequent study of 463 infertile men using the same study design [15] and to some extent by a smaller study including 45 infertility clinic clients from the Great Lakes Region in US [50]. In line are also results of a study performed in India. A negative correlation between semen DEHP metabolites' level and sperm concentration, motility, $\%$ of abnormal sperm was found in a population of men that visited an infertility clinic [51].

In the US population studied by Hauser and Duty, there was evidence of sperm DNA damage as assessed by the neutral comet assay, in association with increasing exposure to MEP and MEHP [53,54]. Duty noticed that for an interquartile range increase in specific gravity-adjusted MEP level, the comet extent increased by $3.6 \mu \mathrm{m}$ and tail distributed moment (TDM) by $1.2 \mu$ m [54]. Also Hauser noticed that MEP was asociated with increased DNA damage while such effect for MEHP was observed after adjustment for the oxidative DEHP metabolites. Comet extent (CE), tail distributed moment (TDM) and Tail\% increased by $17.3 \%, 14.3 \%$ and $17.5 \%$, respectively, for an interquartile range increase in urinary MEHP [53].

Another study performed by Duty and co-workers [14] showed that an interquartile range (IQR) change in $\mathrm{MBz} P$ exposure was significantly associated with a $10 \%$ decrease in FSH concentration. Additionally, an IQR change in MBP exposure was associated with a $4.8 \%$ increase in inhibin B, but this was of borderline significance [14]. Similarly in a Swedish study, Jonsson et al. (2005) [49] reported that subjects within the highest quartile for MEP had fewer motile sperms, more immotile sperms, and lower luteinizing hormone values.

However, in the study in China there was no significant relation between phthalate concentrations and sperm density and liveability and there was a significant positive association between liquefied time of semen and phthalate (DEP, DBP, DEHP) concentrations of semen [52].

Summing up, results of several studies of subfertile men demonstrate associations between phthalate levels commonly experienced by the public and impaired sperm quality (impact on sperm concentration, morphology, motility), but findings have not been corroborated in studies of men from the general population. Effects of phthalates in sexually mature rodents have only been seen at much higher exposure levels, which suggest higher susceptibility of human males. It remains to be investigated if maternal exposure to phthalates have bearings as to semen quality in the offspring. Long term prospective studies of boys exposed in utero to phthalates would be needed to answer this question.

\section{Children's neurodevelopment}

As experimental studies suggest that higher levels of DEHP may have adverse effects on neurobehavioral parameters in mice [12], there is growing concern about the adverse effects of phthalates on children's neurodevelopment. In recent years, there has been concern about mental conditions, ranging from cognitive impairment to schizophrenia, that have been linked to endocrine disruption [55]. Animal studies have also revealed that the phthalate might cause hyperactivity similar to the clinical syndrome of attention-deficit/hyperactivity disorder (ADHD) found in children [56].

Exposures to phthalates have been examined in relation to neurodevelopment among neonates 5 days after birth in United States [57], in Korea in children from elementary schools [58,59] and in United States both among children 4-9 years [60] and 3.6-6.4 years of age [61] (Table 4). In the study performed among neonates enrolled in a multiethnic birth cohort at the Mount Sinai School of Medicine in New York City, maternal urinary concentrations of phthalate metabolites and neonatal behaviors measured within 5 days of birth using the Brazelton Neonatal Behavioral Assessment Scale were evaluated. There were strong, inverse associations between increasing concentrations of high molecular weight phthalate metabolites [MBzP, mono-(2-ethyl-5-carboxypentyl) phthalate (MECPP), 
Table 4. Exposure to phthalates and children's neurodevelopment

\begin{tabular}{|c|c|c|c|c|c|}
\hline Study population & $\begin{array}{l}\text { Type of } \\
\text { study }\end{array}$ & $\begin{array}{c}\text { Definition of } \\
\text { exposure }\end{array}$ & Test used & Results & References \\
\hline $\begin{array}{l}\text { US, New York City } \\
404 \text { women; } \\
188 \text { children } \\
\text { between the ages } \\
\text { of } 4 \text { and } 9 \text { years }\end{array}$ & $\begin{array}{l}\text { Cohort } \\
\text { study }\end{array}$ & $\begin{array}{l}\text { Third-trimester } \\
\text { maternal urines } \\
\text { were collected } \\
\text { and analyzed } \\
\text { for } 10 \text { phthalate } \\
\text { metabolites } \\
\text { (MECPP, MEHHP, } \\
\text { MEOHP, MEHP, } \\
\text { MBzP, MCPP, } \\
\text { MiBP, MBP, MEP, } \\
\text { MMP) }\end{array}$ & $\begin{array}{l}\text { Parent-report } \\
\text { forms of the } \\
\text { Behavior Rating } \\
\text { Inventory of } \\
\text { Executive } \\
\text { Function (BRIEF) } \\
\text { and Behavior } \\
\text { Assessment } \\
\text { System for } \\
\text { Children-Parent } \\
\text { Rating Scales } \\
\text { (BASC-PRS) }\end{array}$ & $\begin{array}{l}\text { Increased } \log _{e} \text { concentrations of low } \\
\text { molecular weight (LMW) phthalate } \\
\text { metabolites were associated with } \\
\text { poorer scores on the clinical scale: } \\
\text { aggression: } 1.24 \text { (95\% CI: 0.15- 2.34), } \\
\text { conduct problems: } \\
2.40 \text { (95\% CI: } 1.34-3.46), \\
\text { attention problems: } \\
\text { 1.29 (95\% CI: 0.16- 2.41), } \\
\text { depression: } 1.18 \text { (95\% CI: } 0.11-2.24) \\
\text { Composite scale: } \\
\text { externalizing problems: } \\
\text { 1.75 (95\% CI: 0.61-2.88), } \\
\text { behavioral symptom index: } \\
\text { 1.55 (95\% CI: 0.39-2.71) } \\
\text { Global Executive composite } \\
\text { index: } 1.23 \text { (95\% CI: } 0.09-2.36) \\
\text { Emotional control scale: } \\
\text { 1.33 (95\% CI: } 0.18-2.49)\end{array}$ & Engel $2010[69$ \\
\hline $\begin{array}{l}\text { South Korea } \\
667 \text { children at } \\
\text { nine elementary } \\
\text { schools in five } \\
\text { South Korean } \\
\text { cities }\end{array}$ & $\begin{array}{l}\text { A cross- } \\
\text { sectional } \\
\text { study }\end{array}$ & $\begin{array}{l}\text { Concentrations } \\
\text { of } 3 \text { urinary } \\
\text { phthalate } \\
\text { metabolites } \\
\text { (MEHP, MEOHP, } \\
\text { MBP) }\end{array}$ & $\begin{array}{l}\text { Korean } \\
\text { Educational } \\
\text { Development } \\
\text { Institute-Wechsler } \\
\text { Intelligence Scale } \\
\text { for Children } \\
\text { (KEDI-WISC) } \\
\text { and Korean } \\
\text { Wechsler Adult } \\
\text { Intelligence Scale } \\
\text { (K-WAIS) for } \\
\text { mothers }\end{array}$ & $\begin{array}{l}\text { Significant negative relationship } \\
\text { between the urine concentrations of } \\
\text { the metabolites of DEHP and DBP } \\
\text { and children's vocabulary subscores } \\
\text { after controlling for maternal IQ. } \\
\text { Among boys - negative } \\
\text { association between increasing } \\
\text { MEHP phthalate concentrations } \\
\text { and the sum of DEHP metabolite } \\
\text { concentrations and Wechsler } \\
\text { Intelligence Scale for Children } \\
\text { vocabulary score; however, among } \\
\text { girls - no significant association } \\
\text { between these variables were found }\end{array}$ & Cho 2010 [68] \\
\hline $\begin{array}{l}\text { Seul, Korea } \\
261 \text { Korean } \\
\text { children, age: } \\
\text { 8-11 years }\end{array}$ & $\begin{array}{l}\text { Cross- } \\
\text { sectional } \\
\text { study }\end{array}$ & $\begin{array}{l}\text { Concentrations } \\
\text { of } 5 \text { urinary } \\
\text { phthalate } \\
\text { metabolites } \\
\text { (MEHP, MEOP, } \\
\text { MEHP+ MEOP, } \\
\text { MNBP, MBP) }\end{array}$ & $\begin{array}{l}\text { Korean } \\
\text { Educational } \\
\text { Development } \\
\text { Institute-Wechsler } \\
\text { Intelligence } \\
\text { Scales (KEDI- } \\
\text { WISC), which } \\
\text { test vocabulary, } \\
\text { arithmetic, picture } \\
\text { arrangement, and } \\
\text { block design }\end{array}$ & $\begin{array}{l}\text { Teacher-rated ADHD scores were } \\
\text { significantly associated with DEHP } \\
\text { metabolites but not with DBP } \\
\text { metabolites. Significant relationships } \\
\text { were also found between the urine } \\
\text { concentrations of metabolites for } \\
\text { DBP and the number of omission } \\
\text { and commission errors in continuous } \\
\text { performance tests }\end{array}$ & Kim 2009 [67] \\
\hline
\end{tabular}


Table 4. Exposure to phthalates and children's neurodevelopment — cont.

\begin{tabular}{|c|c|c|c|c|c|}
\hline Study population & $\begin{array}{l}\text { Type of } \\
\text { study }\end{array}$ & $\begin{array}{c}\text { Definition of } \\
\text { exposure }\end{array}$ & Test used & Results & References \\
\hline $\begin{array}{l}\text { United States } \\
\text { Clinics affiliated } \\
\text { with university } \\
\text { hospitals in } \\
\text { Los Angeles, } \\
\text { Minneapolis, } \\
\text { Columbia and } \\
\text { in Iowa City; } \\
74 \text { boys and } 71 \text { girls } \\
\text { (3.6-6.4 years } \\
\text { of age) }\end{array}$ & $\begin{array}{l}\text { Multicenter } \\
\text { pregnancy } \\
\text { cohort study }\end{array}$ & $\begin{array}{l}\text { Urine samples } \\
\text { were collected } \\
\text { during mid- } \\
\text { pregnancy at } \\
\text { the time of the } \\
\text { mother's prenatal } \\
\text { visit; } 5 \text { phthalate } \\
\text { metabolities were } \\
\text { measured (MEHP, } \\
\text { MEHHP, MEOHP, } \\
\text { MnBP, MiBP) }\end{array}$ & $\begin{array}{l}\text { Preschool } \\
\text { Activities } \\
\text { Inventory (PSAI) } \\
\text { is designed to } \\
\text { discriminate } \\
\text { play behaviour } \\
\text { both within and } \\
\text { between the sexes } \\
\text { as well as a brief } \\
\text { questionnaire that } \\
\text { included questions } \\
\text { on other relevant } \\
\text { covariates (such as } \\
\text { age, number } \\
\text { and age of } \\
\text { siblings, parental } \\
\text { education and } \\
\text { questions on } \\
\text { parental attitudes } \\
\text { towards sex- } \\
\text { atypical toy } \\
\text { choice) }\end{array}$ & $\begin{array}{l}\text { Concentrations of MnBP MiBP } \\
\text { and their sum, were associated } \\
\text { with a decreased (less masculine) } \\
\text { composite score in boys. } \\
\text { Concentrations of two urinary } \\
\text { metabolites DEHP, MEOHP } \\
\text { and MEHHP and the sum of } \\
\text { these DEHP metabolites plus } \\
\text { mono(2-ethylhexyl) phthalate } \\
\text { were associated with a decreased } \\
\text { masculine score }\end{array}$ & Swan 2009 [70] \\
\hline $\begin{array}{l}\text { United States, } \\
\text { New York City } \\
295 \text { children } \\
\text { enrolled in } \\
\text { a multiethnic } \\
\text { birth cohort } \\
\text { between } 1998 \\
\text { and } 2002 \text { at the } \\
\text { Mount Sinai } \\
\text { School of Medicine }\end{array}$ & $\begin{array}{l}\text { Cohort } \\
\text { study }\end{array}$ & $\begin{array}{l}\text { Metabolites of } 10 \\
\text { phthalate esters } \\
\text { in maternal urine } \\
\text { between } 25 \text { and } 40 \\
\text { weeks gestation } \\
\text { were measured } \\
\text { (MMP, MEP, MBP, } \\
\text { MiBP, MBzP, } \\
\text { MECPP, MEHHP, } \\
\text { MEOHP, MEHP, } \\
\text { MCPP) }\end{array}$ & $\begin{array}{l}\text { Brazelton } \\
\text { Neonatal } \\
\text { Behavioral } \\
\text { Assessment Scale } \\
\text { (BNBAS) to } \\
\text { children } \\
\text { within } 5 \text { days } \\
\text { of delivery }\end{array}$ & $\begin{array}{l}\text { Among girls, there was a significant } \\
\text { linear decline in adjusted mean } \\
\text { Orientation score with increasing } \\
\text { urinary concentrations of high } \\
\text { molecular weight phthalate } \\
\text { metabolites }(\mathrm{p}=0.02) \text {. Likewise, } \\
\text { there was a strong linear decline } \\
\text { in their adjusted mean Quality of } \\
\text { Alertness score }(\mathrm{p}<0.01) \text {. } \\
\text { Indication of improved motor } \\
\text { performance with increasing } \\
\text { concentration of low molecular weight } \\
\text { phthalate metabolites among boys }\end{array}$ & Engel 2009 [66] \\
\hline
\end{tabular}

Abbreviations as in Tables 1 and 3.

Low molecular weight phthalate - MMP, MEP, MBP, MiBP.

High molecular weight phthalate - MBzP, MECPP, MEOHP, MEHP, MCPP.

MEHHP, MEOHP, MEHP, mono-(3-carboxypropyl) phthalate (MCPP)] and orientation scores among girls. Similarly, there was an inverse association between high molecular weight metabolite concentrations and Quality of Alertness scores among girls. Among boys, there appeared to be a slight positive association between increasing low molecular weight metabolite concentrations (MMP, MEP, MBP, MiBP) and motor performance [57]. In childhood, phthalate exposure was associated with attention deficit hyperactivity disorder (ADHD) in 
a cross-sectional study of South Korean children between the ages of 8 and 11 years [58]. Another study performed in South Korea among 667 elementary schools children evaluated a relationship between the urine concentrations of the metabolites of DEHP and DBP and children's vocabulary scores. Among boys, but not girls, a negative association was found between increasing MEHP phthalate concentrations and the sum of DEHP metabolite levels and vocabulary score [59].

The association of prenatal phthalate exposure with behavior and executive functioning at 4-9 years of age was examined in multiethnic prenatal population in New York City. However, in multivariate adjusted models, increasing $\log _{e}$ concentrations of low molecular weight phthalate metabolites (MBP, MEP, MiBP, MMP) were significantly associated only with poorer scores on conduct problems [60]. Another study in the United States assessed the play behavior in relation to phthalate metabolites [MEHP, MEHHP, MEOHP, EDEHP, mono-n-butyl phthalate (MNBP), MiBP, $\Sigma \mathrm{DBP}]$ concentration in prenatal urine samples. Phthalate metabolites measured in mid-pregnancy urine samples showed that concentrations of phthalate metabolites were associated with a decreased (less masculine) composite score in boys [61].
The findings of the reviewed studies indicate that children's exposure to phthalates (MBzP, MECPP, MEHHP, MEOHP, MEHP, MCPP, MMP, MEP, MBP, MiBP, ¿DEHP, $2 \mathrm{DBP}$ ) may bring about impairments in the neurodevelopmental processes. The observed risks are generally presumed to be related to the endocrine altering properties of these chemicals [57,61]. In all those studies, exposure to phthalates was associated with neurodevelopmental disorders reflected by significantly poorer scores on conduct problems [60], quality of alertness among girls [57], decreased (less masculine) composite score in boys [61] and lower concentrations and vocabulary score among boys [59] as well as attention deficit hyperactivity disorder (ADHD) [58].

\section{Thyroid function in children}

A normal thyroid function is important for growth and neurological development in children, and hypothyroidism in childhood is accompanied by growth retardation. A growing number of reports have indicated that phthalates can interfere with thyroid function in pregnant women [62] and men [63]. However, so far only one study examined phthalate-related thyroid-disrupting effects in children. In a study performed in Denmark among 845 children 4-9 years

Table 5. Exposure to phthalates and thyroid function

\begin{tabular}{|c|c|c|c|c|c|}
\hline Study population & $\begin{array}{l}\text { Type of } \\
\text { study }\end{array}$ & $\begin{array}{c}\text { Definition of } \\
\text { exposure }\end{array}$ & Outcome & Results & References \\
\hline $\begin{array}{l}\text { Denmark } \\
845 \text { children } \\
4-9 \text { years of age }\end{array}$ & $\begin{array}{l}\text { Cohort } \\
\text { study }\end{array}$ & $\begin{array}{l}12 \text { phthalate } \\
\text { metabolites in urine } \\
\text { (MEP, MBP, MBzP, } \\
\text { MEHP, MEHHP, } \\
\text { MEOHP, MECPP, } \\
\text { MOP, MiNP, MHiNP, } \\
\text { MOiNP, MCiOP) }\end{array}$ & $\begin{array}{l}\text { Thyroid function, } \\
\text { Insulin-like } \\
\text { growth factor I, } \\
\text { growth }\end{array}$ & $\begin{array}{l}\text { Phthalate metabolites were } \\
\text { negatively associated with } \\
\text { serum levels of free and total } \\
\text { triiodothyronine. Metabolites } \\
\text { of di-(2-ethylhexyl) phthalate } \\
\text { and diisononyl phthalate were } \\
\text { negatively associated with } \\
\text { IGF-I in boys. Most phthalate } \\
\text { metabolites were negatively } \\
\text { associated with height, weight, } \\
\text { body surface, and height gain in } \\
\text { both sexes }\end{array}$ & Boas 2010[73] \\
\hline
\end{tabular}

Abbreviations as in Tables 1 and 3. 
of age, the concentrations of phthalate metabolites in urine samples and their association with thyroid function, insulin-like growth factor I (IGF-I), and growth parameters in children were assessed. The authors noticed that in girls, phthalate metabolites were negatively associated with serum levels of free and total triiodothyronine, while metabolites of DEHP and DiNP phthalate were negatively associated with IGF-I in boys. Urinary phthalate concentrations were negatively associated with childhood growth rate and anthropometric measurements such as height, weight, body surface and weight gain [64] (Table 5).

\section{Precocious puberty}

In females, the physical signs associated with the onset of puberty are enlargement of the breasts, ovaries, and uterus, as well as the growth of pubic and axillary hair with apocrine secretion. The process by which puberty occurs is primarily regulated by the endocrine system through its chemical messengers, specifically the sexual hormones [65]. Only in a small percentage of cases there is an underlying medical condition such as a pituitary tumor [66].
Precocious puberty is of particular concern in women because early timing of puberty is associated with the development of breast cancer [67]. Recently Lopez-Carrillo and co-workers [68] examined the association between urinary concentrations of phthalate metabolites and breast cancer in Mexican women [68]. MEP urinary concentrations were positively associated with breast cancer. Risk was even stronger when estimated for premenopausal women. Pubertal gynecomastia referring to the enlargement of male breasts attributable to the proliferation of ductile elements, is a common problem occurring in up to $65 \%$ of adolescent boys [69]. In the study performed in Turkey, Durmaz et al. [70] determined the plasma DEHP and MEHP levels in pubertal gynecomastia cases [70]. Plasma DEHP and MEHP levels were found to be statistically significantly higher in the pubertal gynecomastia group compared with the control group. In the pubertal gynecomastia group, no correlation was determined between plasma DEHP and MEHP levels and any of the examined hormone levels (luteinizing hormone (LH), follicle-stimulating hormone (FSH), estradiol, prolactin, thyrotropin, free triiodothyronine (FT3), free thyroxine (FT4)) [70] (Table 6).

Table 6. Exposure to phthalates and precocious puberty

\begin{tabular}{|c|c|c|c|c|c|}
\hline Study population & $\begin{array}{l}\text { Type of } \\
\text { study }\end{array}$ & $\begin{array}{l}\text { Definition of } \\
\text { exposure }\end{array}$ & Outcome & Results & References \\
\hline $\begin{array}{l}\text { Turkey } \\
40 \text { newly } \\
\text { diagnosed pubertal } \\
\text { gynecomastia cases } \\
\text { who were admitted } \\
\text { to Hacettepe } \\
\text { University } \\
\text { Children's Hospital. } \\
\text { The control group } \\
\text { comprised } 21 \\
\text { age-matched } \\
\text { children without } \\
\text { gynecomastia or } \\
\text { other endocrinologic } \\
\text { disorder }\end{array}$ & $\begin{array}{l}\text { Case- } \\
\text { control }\end{array}$ & $\begin{array}{l}\text { DEHP and MEHP } \\
\text { levels in plasma }\end{array}$ & $\begin{array}{l}\text { Pubertal } \\
\text { gynecomastia }\end{array}$ & $\begin{array}{l}\text { Plasma DEHP and MEHP } \\
\text { levels were found to be } \\
\text { statistically significantly higher } \\
\text { in the pubertal gynecomastia } \\
\text { group compared with the } \\
\text { control group } \\
\text { DEHP: OR = 2.77 } \\
\text { (95\% CI: } 1.48-5.21 \text { ), } \\
\text { MEHP: } 24.76 \\
\text { (95\% CI: } 3.5-172.6)\end{array}$ & Durmaz 2010 [79] \\
\hline
\end{tabular}


Table 6. Exposure to phthalates and precocious puberty — cont.

\begin{tabular}{|c|c|c|c|c|c|}
\hline Study population & $\begin{array}{l}\text { Type of } \\
\text { study }\end{array}$ & $\begin{array}{l}\text { Definition of } \\
\text { exposure }\end{array}$ & Outcome & Results & References \\
\hline $\begin{array}{l}\text { United States } \\
28 \text { girls with central } \\
\text { precocious puberty } \\
(\mathrm{CPP}) \text { and } 28 \text { age- } \\
\text { and race-matched } \\
\text { prepubertal females }\end{array}$ & $\begin{array}{l}\text { Multicenter } \\
\text { cross- } \\
\text { sectional }\end{array}$ & $\begin{array}{l}9 \text { phthalate } \\
\text { metabolites in } \\
\text { urine (MBP, MBzP, } \\
\text { MCPP, MECPP, } \\
\text { MEHP, MEHPP, } \\
\text { MEOHP, MiBP, } \\
\text { MEP) }\end{array}$ & $\begin{array}{l}\text { Precocious } \\
\text { puberty (CPP) }\end{array}$ & $\begin{array}{l}\text { No significant differences } \\
\text { between the children with } \\
\text { CPP and the controls in } \\
\text { either absolute or creatinine- } \\
\text { normalized concentrations } \\
\text { of any of the } 9 \text { phthalate } \\
\text { metabolites were found }\end{array}$ & Lomenick 2010 [82] \\
\hline $\begin{array}{l}\text { China, Shanghai } \\
110 \text { precocious girls } \\
\text { and } 100 \text { control } \\
\text { children }\end{array}$ & $\begin{array}{l}\text { Case- } \\
\text { control }\end{array}$ & $\begin{array}{l}\text { Serum level of: } \\
\text { DBP and DEHP }\end{array}$ & $\begin{array}{l}\text { Precocious } \\
\text { puberty }\end{array}$ & $\begin{array}{l}\text { Precocious girls' uterus and } \\
\text { ovary volumes were higher } \\
\text { than those of normal children } \\
\text { respectively }(\mathrm{p}<0.05, \\
\mathrm{p}<0.05) \text {. DBP in serum of } \\
\text { precocious girls had positive } \\
\text { correlation with the volumes } \\
\text { of the uteruses ( } \mathrm{r}=0.456 \text {, } \\
\mathrm{p}<0.05) \text {, and had positive } \\
\text { correlation with volumes of the } \\
\text { ovaries ( } \mathrm{r}=0.378, \mathrm{p}<0.01) \text {. } \\
\text { DEHP in serum of precocious } \\
\text { puberty had positive correlation } \\
\text { with the volumes of uteruses } \\
(\mathrm{r}=0.382, \mathrm{p}<0.05) \text {, and } \\
\text { had positive correlation with } \\
\text { volumes of ovaries ( } \mathrm{r}=0.689 \text {, } \\
\mathrm{p}<0.01)\end{array}$ & Qiao 2007 [81] \\
\hline $\begin{array}{l}\text { Puerto Rico } \\
41 \text { samples from } \\
\text { thelarche patients } \\
\text { and } 35 \text { control (girls } \\
\text { younger than } 8 \text { years } \\
\text { of age) }\end{array}$ & $\begin{array}{l}\text { Cross- } \\
\text { sectional } \\
\text { study }\end{array}$ & $\begin{array}{l}\text { Blood serum } \\
\text { analysis of DEHP, } \\
\text { MEHP, DOP, BBP, } \\
\text { DEP, DBP }\end{array}$ & $\begin{array}{l}\text { Premature } \\
\text { thelarche }\end{array}$ & $\begin{array}{l}\text { Significantly high levels of } \\
\text { phthalates (DMP, DEP, } \\
\text { DBP, DEHP and its major } \\
\text { metabolite, MEHP) were } \\
\text { identified in } 28(68 \%) \text { samples } \\
\text { from thelarche patients }\end{array}$ & Colon 2000 [80] \\
\hline
\end{tabular}

Abbreviations as in Tables 1 and 3.

Colón et al. [71] reported that levels of phthalates, particularly DEHP in serum of Puerto Rico girls with premature thelarche were statistically significantly higher compared with the control girls.

In the study conducted in China, DEHP levels in girls with precocious puberty were found to be higher compared with the control group. It was noted also that girls with higher DEHP levels have larger ovarian and uterus size [72] (Table 6). In the United States, in a multicenter cross-sectional study among 28 girls with central precocious puberty (CPP) and 28 age- and race-matched prepubertal females no significant differences in effects of either absolute or creatinine-normalized concentrations of any of the phthalate metabolites (MBP, MBzP, MCPP, MECPP, MEHP, MEHPP, MEOHP, MiBP, MEP) were found [73] (Table 7). 
Table 7. Exposure to phthalates and respiratory problems

\begin{tabular}{|c|c|c|c|c|c|}
\hline Study population & $\begin{array}{l}\text { Type of } \\
\text { study }\end{array}$ & Exposure & Outcome & Results & References \\
\hline $\begin{array}{l}\text { Sweden } \\
4779 \text { children } \\
\text { (1-3 years at baseline } \\
\text { and 6-8 years } \\
\text { at follow up) }\end{array}$ & $\begin{array}{l}\text { Cohort } \\
\text { study }\end{array}$ & $\begin{array}{l}\text { The questionnaire included } \\
\text { questions on building } \\
\text { characteristics, and flooring } \\
\text { materials in the bedrooms } \\
\text { (PVC, plastic cork, wood, } \\
\text { linoleum, stone, and wall- } \\
\text { to-wall carpet) }\end{array}$ & $\begin{array}{l}\text { Asthma, } \\
\text { rhinitis, } \\
\text { and eczema }\end{array}$ & $\begin{array}{l}\text { Adjusted analyses showed that } \\
\text { the incidence of asthma among } \\
\text { children was associated with PVC- } \\
\text { flooring in the child's bedroom } \\
(\mathrm{OR}=1.52 ; 95 \% \text { CI: } 0.99-2.35) \\
\text { and in the parent's bedroom } \\
(\mathrm{OR}=1.46 ; 95 \% \text { CI: } 0.96-2.23)\end{array}$ & $\begin{array}{l}\text { Larsson } \\
2010 \text { [87] }\end{array}$ \\
\hline $\begin{array}{l}\text { Bułgaria } \\
\text { A total of } 102 \text { children } \\
\text { ( } 2-7 \text { years of age) with } \\
\text { symptoms of wheezing, } \\
\text { rhinitis, and/or eczema } \\
\text { in preceding } 12 \text { months } \\
\text { (cases), and } 82 \text { were } \\
\text { nonsymptomatic } \\
\text { (controls) }\end{array}$ & $\begin{array}{l}\text { Cross- } \\
\text { sectional } \\
\text { study }\end{array}$ & $\begin{array}{l}\text { Dust samples from the } \\
\text { child's bedroom were } \\
\text { collected. The dust samples } \\
\text { were analyzed for their } \\
\text { content of DMP, DEP, } \\
\text { DnBP, BBzP, DnOP }\end{array}$ & $\begin{array}{l}\text { Wheezing, } \\
\text { rhinitis, } \\
\text { eczema }\end{array}$ & $\begin{array}{l}\text { The concentration of DEHP } \\
\text { was significantly associated with } \\
\text { wheezing in the preceding } 12 \text { months } \\
(\mathrm{p}=0.035) \text { as reported by parents. } \\
\text { A dose-response relationship } \\
\text { between DEHP concentration and } \\
\text { case status and between DEHP } \\
\text { concentration and wheezing in the } \\
\text { preceding } 12 \text { months was found }\end{array}$ & $\begin{array}{l}\text { Kolarik } \\
2008 \text { [24] }\end{array}$ \\
\hline $\begin{array}{l}\text { Sweden } \\
10851 \text { children } \\
\text { (1-6 years) }\end{array}$ & $\begin{array}{l}\text { Cross- } \\
\text { sectional } \\
\text { study }\end{array}$ & $\begin{array}{l}\text { Parental reported PCV } \\
\text { flooring in sleeping rooms }\end{array}$ & $\begin{array}{l}\text { Wheezing, } \\
\text { cough } \\
\text { at night, } \\
\text { asthma, } \\
\text { rhinitis, } \\
\text { eczema }\end{array}$ & $\begin{array}{l}\text { The combination of water leakage } \\
\text { in the home and PVC as flooring } \\
\text { material in the child's or parent's } \\
\text { bedroom was associated to higher } \\
\text { prevalence of airways symptoms } \\
\text { among children }\end{array}$ & $\begin{array}{l}\text { Bornehag } \\
2005 \text { [33] }\end{array}$ \\
\hline $\begin{array}{l}\text { Sweden } \\
198 \text { cases with } \\
\text { persistent allergic } \\
\text { symptoms and } 202 \\
\text { controls without } \\
\text { allergic symptoms } \\
\text { (3-8 years of age) }\end{array}$ & $\begin{array}{l}\text { Nested } \\
\text { case- } \\
\text { control } \\
\text { study }\end{array}$ & $\begin{array}{l}\text { Dust samples were collected } \\
\text { from molding and shelves } \\
\text { in children's bedroom. } \\
\text { Dust concentrations of six } \\
\text { phthalates were determined } \\
\text { (DEP, DIBP, DnBP, BBzP, } \\
\text { DEHP, DINP }\end{array}$ & $\begin{array}{l}\text { rhinitis, } \\
\text { eczema, } \\
\text { asthma }\end{array}$ & $\begin{array}{l}\text { Higher median concentrations of } \\
\text { BBzP in dust among cases than } \\
\text { among controls }(0.15 \mathrm{vs} .0 .12 \mathrm{mg} / \mathrm{g} \\
\text { dust) was found. Analyzing the case } \\
\text { group by symptoms showed that } \\
\text { BBzP was associated with rhinitis } \\
(\mathrm{p}=0.001) \text { and eczema }(\mathrm{p}=0.001) \text {, } \\
\text { whereas DEHP was associated with } \\
\text { asthma ( } \mathrm{p}=0.022)\end{array}$ & $\begin{array}{l}\text { Bornehag } \\
2004 \text { [23] }\end{array}$ \\
\hline $\begin{array}{l}\text { Russia (nine cities) } \\
\text { 5951 Russian } \\
\text { 8-12-year-old } \\
\text { schoolchildren }\end{array}$ & $\begin{array}{l}\text { Cross- } \\
\text { sectional } \\
\text { study }\end{array}$ & $\begin{array}{l}\text { Exposure assessment was } \\
\text { based on the following } \\
\text { question: "Have you } \\
\text { conducted any of the } \\
\text { following renovations in } \\
\text { your home within } \\
\text { the past } 12 \text { months or } \\
\text { earlier?" The choices } \\
\text { were installation of } \\
\text { linoleum floor, painting, } \\
\text { particleboard, new } \\
\text { furniture, synthetic } \\
\text { carpet, wall covering, and } \\
\text { suspended ceiling }\end{array}$ & $\begin{array}{l}\text { Current } \\
\text { asthma, } \\
\text { wheezing, } \\
\text { and allergy }\end{array}$ & $\begin{array}{l}\text { The risks of current wheezing } \\
\text { (OR = 1.36; 95\% CI: } 1.00-1.86) \\
\text { and allergy (OR = 1.31; } \\
95 \% \text { CI: } 1.05-1.65) \text { were significantly } \\
\text { related to the installation of linoleum } \\
\text { flooring during the past } 12 \text { months }\end{array}$ & $\begin{array}{l}\text { Jaakkola } \\
2004[86]\end{array}$ \\
\hline
\end{tabular}


Table 7. Exposure to phthalates and respiratory problems — cont.

\begin{tabular}{|c|c|c|c|c|c|}
\hline Study population & $\begin{array}{l}\text { Type of } \\
\text { study }\end{array}$ & Exposure & Outcome & Results & References \\
\hline $\begin{array}{l}\text { Finland } \\
2568 \text { Finnish children } \\
\text { aged 1-7 years }\end{array}$ & $\begin{array}{l}\text { Cross- } \\
\text { sectional } \\
\text { study }\end{array}$ & $\begin{array}{l}\text { Parents responses to } \\
\text { a question assessing the } \\
\text { proportion of plastic wall } \\
\text { surfaces in the home }\end{array}$ & $\begin{array}{l}\text { Current } \\
\text { asthma, } \\
\text { allergic } \\
\text { rhinitis, } \\
\text { persistent } \\
\text { wheezing, } \\
\text { persistent } \\
\text { cough, } \\
\text { persistent } \\
\text { phlegm, } \\
\text { weekly } \\
\text { nasal } \\
\text { congestion/ } \\
\text { excretion, } \\
\text { respiratory } \\
\text { infections }\end{array}$ & $\begin{array}{l}\text { Lower respiratory tract } \\
\text { symptoms - persistent wheezing } \\
(\mathrm{OR}=3.42 ; 95 \% \mathrm{CI}: 1.13-10.36) \\
\text { cough (OR = 2.41, } 95 \% \text { CI: } \\
\text { 1.04-5.63), phlegm (OR = 2.76; } \\
95 \% \text { CI: } 1.03-7.41) \text { - were strongly } \\
\text { related to the presence of plastic wall } \\
\text { materials, whereas upper respiratory } \\
\text { symptoms were not. } \\
\text { The risk of asthma (OR = 1.52; } \\
\text { 95\% CI: } 0.35-6.71) \text { and pneumonia } \\
(\mathrm{OR}=1.81 ; 95 \% \text { CI: } 0.62-5.29) \\
\text { was also increased in children } \\
\text { exposed to such materials }\end{array}$ & $\begin{array}{l}\text { Jaakkola } \\
2000 \text { [85] }\end{array}$ \\
\hline
\end{tabular}

DIBP — diisobutyl phthalate; DnBP — di- $n$-butyl phthalate; BBzP — n-butylbenzyl; DINP — diisononyl phthalate; DnOP — di- $n$-octyl phthalate. Other abbreviations as in Table 3.

The results of the most of presented studies indicate that the levels of phthalates were statistically significantly higher in the pubertal gynecomastia groups compared with the controls [70]. Both in case of premature thelarche [71] and precocious puberty [72], levels of DEHP were statistically significantly higher compared with the control girls. However, the last finding was not confirmed in the study performed by Lomenick et al. (2010) [73].

\section{Respiratory problems in children}

In the developed parts of the world, people spend as much as $90 \%$ of their life indoors [74], which implies that indoor environmental conditions are important for their health. On the other hand, there has been an increase in asthma and allergy during the past few decades. Because of the rapid character of this phenomenon, it is believed to be caused by changes in environmental exposures rather than genetic changes [75]. There is accumulating scientific data supporting the hypothesis that exposure to phthalates from soft polyvinyl chloride (PVC) used in building materials and in a huge number of consumer products may be linked to asthma. Cross-sectional studies from Sweden, Russia and Finland showed that both PVC flooring and PVC wall covering material were associated to airway symptoms in children [27,76,77]. Furthermore, two case-control prevalence studies from Sweden and Bulgaria reported an association between the concentration of DEHP in indoor dust and asthma/wheezing in children [23,24]. Finally, in a cohort study in Sweden, parental reported PVC flooring in the child's as well as in the parent's bedroom when children were 1-3 years of age was associated with incident asthma 5 years later [78] (Table 7).

In Finland, in population-based cross-sectional study involving 2568 Finnish children aged 1 to 7 years, plastic wall materials in homes (reported by parents) were significantly associated to airway symptoms: wheezing, cough, phlegm, asthma, pneumonia in adjusted analysis [76]. The second study performed by the same group of authors [77] among 5951 Russian 8-12-year-old schoolchildren 
studied risks of current asthma, wheezing, and allergy with relation to recent renovation and the installation of materials with potential chemical emissions (based on parental questionnaire). PVC and linoleum flooring material was significantly associated with airway symptoms: current wheezing and allergy in adjusted analysis [77].

Another cross-sectional study in Sweden related home characteristics including exposure to PVC flooring and dampness problems to symptoms in airway, nose, and skin among 10851 children (1-6 years) [27]. In this study, PVC flooring in combination with water leakage in the home was significantly associated with airway symptoms (wheezing, rhinitis) in adjusted analysis [27].

In nested case-control study performed by the same group among children 3-8 years of age, benzylbutylphthalate $(\mathrm{BBz})$ was associated with rhinitis and eczema, whereas DEHP was related to asthma [23].

The similar pattern was found in study of children in Sofia and Burgas [24]. Dust samples from the child's bedroom were collected. A dose-response relationship between concentrations of DEHP and increasing prevalence of wheezing in the following 12 months $(p=0.035)$ as reported by parents was found [24].

The most current cohort study was performed in Sweden to examine the association between exposure to PVC flooring in the child's and parent's bedroom in homes of children aged 1-3 and the incidence of asthma, rhinitis, and eczema during the following 5-year period [78]. Exposure assessment was based on parental reporting of PVC flooring in sleeping rooms. PVC-flooring in the child's bedroom and in the parents' bedroom was associated with doctor diagnosed asthma in analysis adjusted for smoking in family, age, sex, allergy in family, single-parenthood, multifamily house [78].

Based on results presented above, there seems to be possible association between exposure to phthalates (DEHP, and $\mathrm{BBz}$ ) and the occurrence of asthma symptoms and allergy. The PCV flooring at home and the plastic wall materials impact on the occurrence of asthma, wheezing, cough and pneumonia.

\section{DISCUSSION}

The results of the reviewed studies suggest that exposure to several phthalates may affect reproductive outcome and children health in terms of gestational age, body size measures, reproductive hormones, genital development, neurodevelopment, thyroid function, semen quality, precocious puberty and respiratory system abnormalities (asthma, wheezing, eczema).

Most of the presented studies found an association between exposure to phthalates (at least one of its metabolites) and semen quality, reproductive outcome (body size measures of the infants at birth such as: gestational age, birth weight, head circumferences, reproductive hormones and genital development) and children health (asthma and allergy symptoms, neurodevelopment, thyroid disruption, precocious puberty).

In contrast, no such association was presented in case of cryptorchidism [38].

The results of the most of presented studies indicate that the levels of phthalates (DEHP, MEHP, DEP, DBP) were statistically significantly higher in the pubertal gynecomastia group and among premature thelarche cases. However, opposite results were also presented [73].

The health effects of exposure to specific type of phthalates are presented in Table 8. Exposure to DEHP and its metabolites (MEHP, MEHHP, MEOHP) negatively affected anogenital distance, children's neurodevelopment, gestational age, DNA damage, sperm concentration, livability, density and morphology, ADHD, level of insulin-like growth factor I and some respiratory problems: asthma and wheezing. On the other hand, the positive correlation was found between DEHP exposure and ovarian and uterus size. Also positive correlation was noticed between MEP and MBP exposure and level of sex-hormone binding globin and ratio of LH. 
DEP and DBP and their metabolites impact the semen parameters: motility, concentration, livability, density, morphology, anogenital distance, level of FSH, LH, free and total T3, DNA damage and children's neurodevelopment. MBzP exposure was associated with anogenital distance, sperm concentration and DNA damage. In case of the effect on respiratory symptoms BBzP concentrations in house dust impact rhinitis and eczema.

The results of the most of presented studies were adjusted for well-known confounders. In studies on exposure to phthalate and children's neurodevelopment for: mother IQ, age, gender, parental education, socioeconomic status, birth weight, history of breast-feeding, residential area. In respiratory symptoms studies: sex, age, smoking at home, type of building, construction period, allergy and asthma in the family, day-care center attendance, dampness problems, pets, birth weight. The results of the studies on reproductive outcome were adjusted for: race, infant sex, gestational age, smoking during pregnancy, maternal education, marital status, prepregnancy BMI. Most of the studies on semen quality were adjusted for age, smoking, BMI and abstinence time in thyroid function studies on age and sex whereas in genital development studies on age and weight. Precocious puberty studies were based on the differences in level of phthalates in cases and control groups.

However, when reviewing the epidemiological studies on the influence of exposure to phthalates and examined health effects, it is important to take into account the current limitations of these studies resulting from inadequacies in exposure assessment, and study design.

\section{Exposure assessment}

Exposure assessment is a crucial part of any area of environmental epidemiology. The best assessment of exposure usually involves measurements of contaminants in urine, blood, semen, amniotic fluid, and breast milk [25]. Exposure in almost all presented studies was based on specific biomarkers of exposure mainly in urine $[8,14,15,18,43,49-54,57-61,64,73]$. As phthalates are metabolized to their monoesters within a few hours or days $[79,80]$, urinary phthalate monoesters are considered good biomarkers for assessing phthalate exposure in humans $[8,62,80-82]$. A study of the variability of phthalate metabolite concentrations in men of reproductive age found that a single urine sample was reasonably predictive of the subject's exposure to the parent phthalate over 3 months [81]. This may reflect habitual use of phthalate-containing household and consumer products. A recent review by Teitelbaum et al. [83] of sources of variability in biomarkers of environmental exposures in minority children, including phthalates, also confirms that a single spot urine sample is sufficiently representative of exposure over a six-month period to warrant its use as an exposure estimate in epidemiological studies.

Critical points of sexual differentiation in the external genitalia in the fetus begin at around 7-17 weeks $[84,85]$. Amniotic fluid obtained from routine amniocentesis at 16-20 weeks of gestation may be a better marker for the assessment of prenatal phthalate exposure during the period of sexual differentiation $[86,87]$. So far, only in one study the phthalate, besides in the urine from pregnant women, were measured in amniotic fluid [45].

Phthalates were also assessed in cord blood [25], plasma [70] blood serum [71,72]. Umbilical cord blood and the placenta are biomarkers of fetal exposure to environmental hormones, especially for persistent organic pollutants $[88,89]$. However, using cord blood or the placenta to evaluate phthalates exposure in the fetus may not represent fetal exposure during the crucial periods [25]. Breast milk samples were analyzed in Danish-Finnish cohort study on cryptorchidism [38]. However, children are exposed to many phthalates simultaneously and exposure through lactation is only one of many potential exposure routes.

Dust concentrations of phthalates were assessed in the studies on respiratory symptoms [23,24]. In those kind of studies also questionnaire including questions on building 


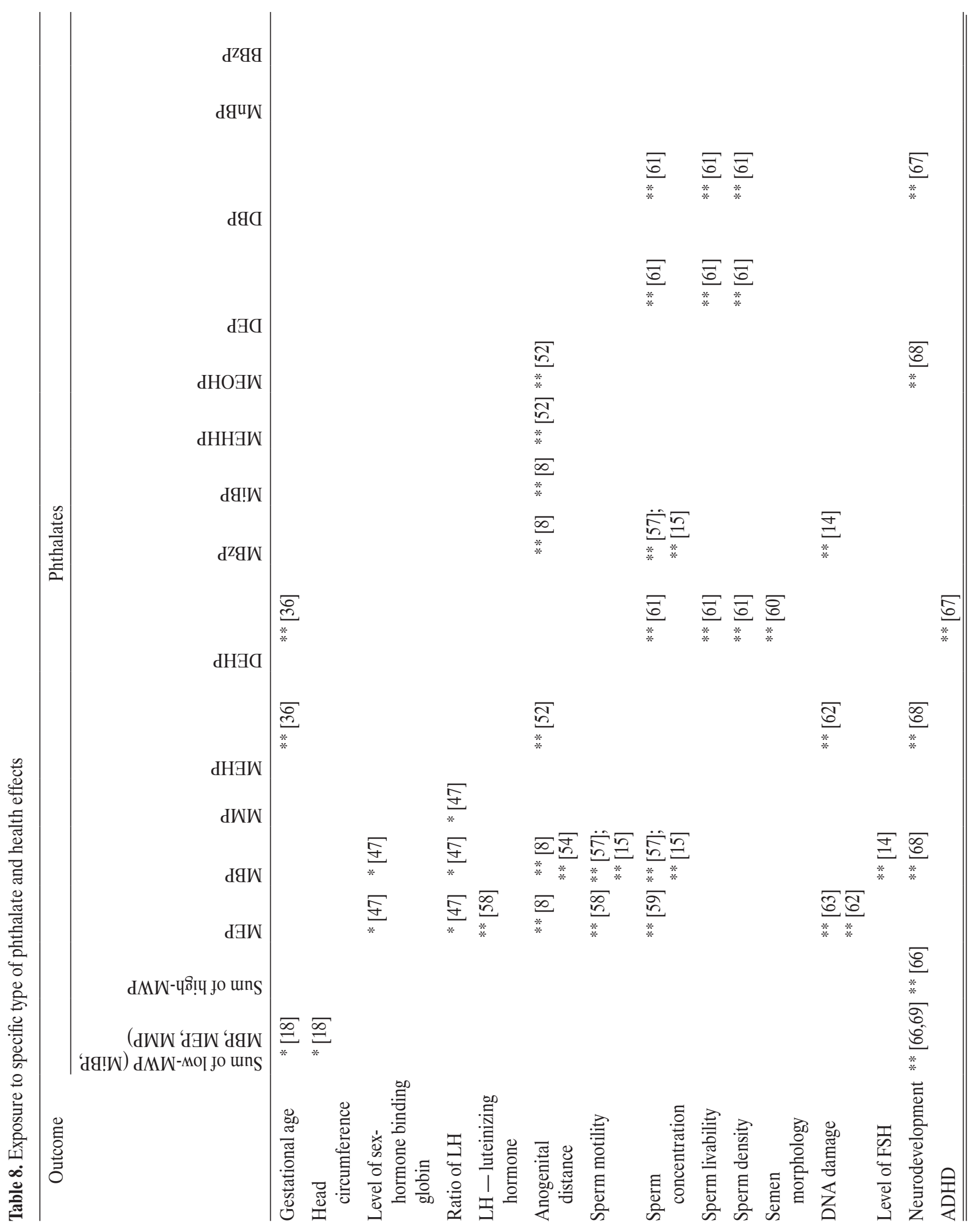




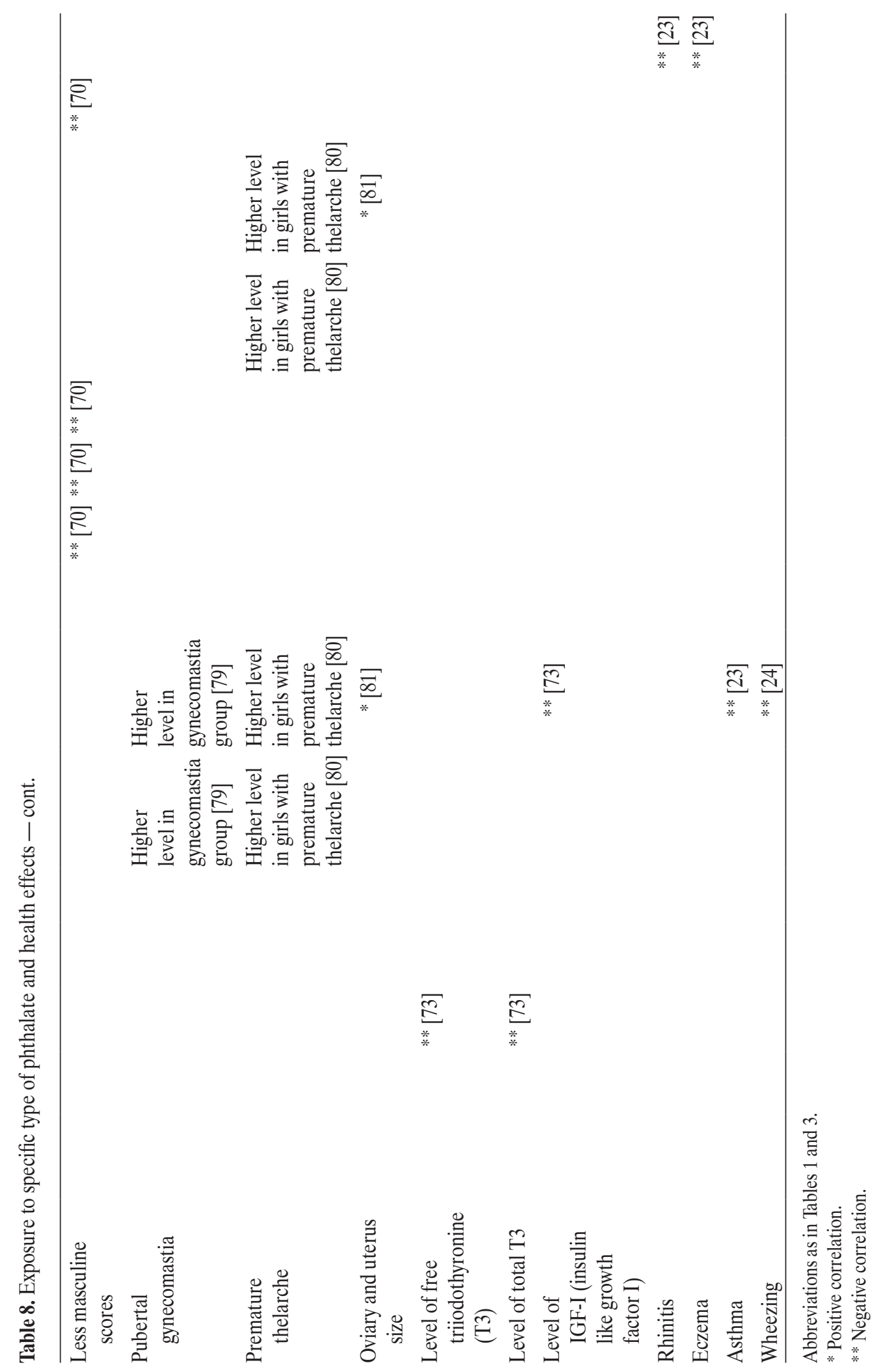


characteristics were used to evaluate the phthalate exposure [27,76-78]. A validation of the questionnaire used in those studies has been reported earlier [90], where parental reports on building characteristics were compared with observations of professional inspectors.

The potential confounding from exposure to other chemicals in most presented studies is unclear. Also the risk from a mixture of phthalates (or phthalates and other antiandrogens), whether acting by similar mechanisms or not, cannot be accurately assessed.

\section{Study design}

In most of the studies reviewed, cross-sectional design were used to assess the exposure to phthalate and children health $[14,15,24,25,27,49-54,58,59,71,73,76,77]$. The cross-sectional approach is most often associated with considerable differential dropout and uncertainty about the comparability of exposed and non-exposed groups. It may be possible to overcome some of the major limitations of studies by choosing a longitudinal design with a follow-up of intraindividual changes. Such prospective design was used in some of the presented studies $[8,18,38,43,57,60-62,64,78]$. Three studies used also casecontrol design $[23,70,72]$.

A low response rate is always a problem in epidemiologic investigations. However, such problems mainly involve representativity and may help avoiding bias when analyzing associations between exposures and health effects. A bias in the study could be introduced if parents with sick children knew the risk factors for their child's illness and reported more of such factors.

\section{Challenges for future studies}

It is necessary to conduct longitudinal studies. Such studies should take into account other factors which may interfere with reproductive system and children health. Future studies should have sufficient power and homogenous groups with an appropriate non-exposed control group.
When the influence of confounding factors is likely, these should be taken into account during the stage of study design and data collection and finally in the statistical analysis. Further evaluation of phthalates which are commonly used substances in human population is highly recommended. The longitudinal design option is a rational answer to several of the main limitations in the cross sectional approach. Longitudinal studies may be the "gold standard" for assessing risks to human health, but these are expensive and take a lot of time. Therefore, they must be augmented by, and closely linked to, animal studies in which mechanism and causality can be demonstrated. While several links between rodent and human studies have been made in this area, as discussed above, these are limited by several discrepancies between human and animal testing.

Because of these important differences in route, dose level, and multiplicity of agents, it is often unclear how to interpret findings across species. For these reasons, if chemical risk assessment is to be relevant to human exposure, future assessments should incorporate more environmentally relevant scenarios, including mixtures.

Epidemiological data is needed in human populations, along with a better mechanistic understanding of the reproductive health effects of phthalates.

\section{CONCLUSION:}

The results from the presented studies suggest that there are strong and rather consistent indications that phthalates impact thyroid function [64] and occurrence of allergy and asthma [23,24,27,76-78]. Low-molecular-weight phthalate monoester metabolites had a positive association with gestational age and with head circumference [18]. Phthalates also have infuence on lower gestational age [25], reproductive hormones (luteinizing hormone - $\mathrm{LH}$ ), free testosterone, sex hormone-binding globulin (SHBG) [38] and anogenital distance $[8,43,45]$. Results of few studies on semen quality demonstrate associations between 
phthalate levels commonly experienced by the public and impaired sperm quality (impact on sperm concentration, morphology, motility).

In spite of their limitations, epidemiological studies suggest awareness of environmental factors which may affect human health. Given the suggested health effects and the wide-spread exposure, more epidemiologic data are urgently needed, and in the meantime, precautionary policies should be implemented.

\section{REFERENCES}

1. Kavlock RJ, Daston GP, DeRosa C, Fenner-Crisp P, Gray LE, et al. Research needs for the risk assessment of health and environmental effects of endocrine disruptors: A report of the US EPA-sponsored workshop. Environ Health Perspect 1996;104:715-40.

2. Api AM. Toxicological profile of diethyl phthalate: a vehicle for fragrance and cosmetic ingredients. Food Chem Toxicol 2001;39:97-108.

3. Arcadi FA, Costa C, Imperatore C, Marchese A, Rapisarda A, Salemi M, et al. Oral toxicity of bis(2-ethylhexyl) phthalate during pregnancy and suckling in the Long-Evans rat. Food Chem Toxicol 1998;36:963-70.

4. Foster PM, Mylchreest E, Gaido KW, Sar M. Effects of phthalate esters on the developing reproductive tract of male rats. Hum Reprod Update 2001;231-5.

5. Gray LE Jr, Ostby J, Furr J, Price M, Veeramachaneni DN, Parks L. Perinatal exposure to the phthalates DEHP, BBP, and DINP, but not DEP, DMP, or DOTP, alters sexual differentiation of the male rat. Toxicol Sci 2000;58:350-65.

6. Moore RW, Rudy TA, Lin TM, Ko K, Peterson RE. Abnormalities of sexual development in male rats with in utero and lactational exposure to the antiandrogenic plasticizer di(2-ethylhexyl) phthalate. Environ Health Perspect 2001;109:229-37.

7. Tandon R, Seth PK, Srivastava SP. Effect of in utero exposure to di(2-ethylhexyl)phthalate on rat testes. Indian J Exp Biol 1991;29:1044-6.
8. Swan SH, Main KM, Liu F, Stewart SL, Kruse SL, Calafat AM, et al. Decrease in anogenital distance among male infants with prenatal phthalate exposure. Environ Health Perspect 2005;113:1056-61.

9. Welsh M, Saunders PT, Fisken M, Scott HM, Hutchison GR, Smith $\mathrm{LB}$, et al. Identification in rats of a programming window for reproductive tract masculinization, disruption of which leads to hypospadias and cryptorchidism. J Clin Invest 2008;118:1479-90.

10. Foster PM. Disruption of reproductive development in male rat offspring following in utero exposure to phthalate esters. Int J Androl 2006;29:140-7.

11. Shape RM, Fisher JS, Millar MM, Jobling S, Sumpter JP. Gestational and lactation exposure of rats to xenoestrogens results in reduced testicular size and sperm production. Environ Health Perspect 1995;103:1136-43.

12. Tanaka T. Reproductive and neurobehavioral effects of bis(2-ethylhexyl) phthalate (DEHP) in a cross-mating toxicity study of mice. Food Chem Toxicol 2005;43:581-9.

13. Shea KM. Pediatric exposure and potential toxicity of phthalate plasticizers. Pediatrics 2003;111:1467-74.

14. Duty SM, Calafat AM, Silva MJ, Ryan L, Hauser R. Phthalate exposure and reproductive hormones in adult men. Hum Reprod 2005;20(3):604-10.

15. Hauser R, Meeker JD, Duty S, Silva MJ, Calafat AM. Altered Semen Quality in Relation to Urinary Concentrations of Phthalate Monoester and Oxidative Metabolites. Epidemiol 2006;17:682-91.

16. Kamrin MA. Phthalate risks, phthalate regulation, and public health: a review. J Toxicol Environ Health B Crit Rev 2009;12:157-74.

17. Sathyanarayana S, Karr CJ, Lozano P, Brown E, Calafat AM, Liu F, et al. Baby Care Products: Possible Sources of Infant Phthalate Exposure. Pediatrics 2008;121(2):e260-8. DOI: $10.1542 /$ peds.2006-3766.

18. Wolff MS, Engel SM, Berkowitz GS, Ye X, Silva MJ, Zhu C, et al. Prenatal phenol and phthalate exposures and birth outcomes. Environ Health Perspect 2008;116:1092-7. 
19. Lottrup AM, Eersson H, Leffers GK, Mortensen J, Toppari NE, Skakkebaek NE, et al. Possible impact of phthalates on infant reproductive health. Int J Androl 2006;29:172-80.

20. Chalubinski M, Kowalski ML. Endocrine disrupters - potential modulators of the immune system and allergic response. Allergy 2006;61:1326-35.

21. Jaakkola JJ, Oie L, Nafstad P, Botten G, Samuelsen SO, Magnus P. Interior surface materials in the home and the development of bronchial obstruction in young children in Oslo, Norway. Am J Pub Health 1999;89:188-92.

22. Øie L, Hersoug L-G, Madsen JØ. Residential exposure to plasticizers and its possible role in the pathogenesis of asthma. Environ Health Perspect 1997;105:972-8.

23. Bornehag CG, Sundell J, Weschler CJ, Sigsgaard T, Lundgren $\mathrm{B}$, Hasselgren $\mathrm{M}$, et al. The association between asthma and allergic symptoms in children and phthalates in house dust: A nested case-control study. Environ Health Perspect 2004;112:1393-7.

24. Kolarik B, Naydenov K, Larsson M, Bornehag CG, Sundell J. The association between phthalates in dust and allergic diseases among Bulgarian children. Environ Health Perspect 2008;116:98-103.

25. Latini G, Felice CD, Presta G, Del Vecchio A, Paris I, Ruggieri $\mathrm{F}$, et al. In utero exposure to di-(2-ethylhexyl) phthalate and duration of human pregnancy. Environ Health Perspect 2003;111:1783-5.

26. National Research Council. Committee on the Health Risks of Phthalates. Phthalates and Cumulative Risk Assessment: The Task Ahead. Washington: National Academies Press; 2008.

27. Bornehag CG, Sundell J, Hagerhed-Engman L, Sigsgaard T, Janson S, Aberg N, et al. "Dampness" at home and its association with airway, nose and skin symptoms among 10851 preschool children in Sweden: A cross sectional study. Indoor Air 2005;15:48-55.

28. Rudel RA, Camann DE, Spengler JD, Korn RL, Brody JG. Phthalates, alkylphenols, pesticides, polybrominated diphenyl ethers, and other endocrine-disrupting compounds in indoor air and dust. Environ Sci Technol 2003;37:4543-53.

29. Wormuth M, Scheringer M, Vollenweider M, Hungerbühler $\mathrm{K}$. What are the sources of exposure to eight frequently used phthalic acid esters in Europeans? Risk Anal 2006;26:803-24.

30. Howdeshell KL, Wilson VS, Furr J, Lambright RC, Rider CV, Blystone RC, Hotchkiss AK et al. A Mixture of Five Phthalate Esters Inhibits Fetal Testicular Testosterone Production in the Sprague-Dawley Rat in a Cumulative, Dose-Additive Manner. Toxicol Sci 2008;105(1):153-65.

31. Sharpe RM. Hormones and testis development and the possible adverse effects of environmental chemicals. Toxicol Lett 2001;120:221-32.

32. Ablake M, Itoh M, Terayama H, Hayashi S, Shoji S, Naito M, et al. Di-(2-ethylhexyl) phthalate induces severe aspermatogenesis in mice, however, subsequent antioxidant vitamins supplementation accelerates regeneration of the seminiferous epithelium. Int J Androl 2004;27:274-81.

33. Latini G, Felice CD, Verrotti A. Plasticizers, infant nutrition and reproductive health. Reprod Toxicol 2004;19:27-33.

34. Calafat AM, Brock JW, Silva MJ, Gray LE, Reidy JA, Barr DB, et al. Urinary and amniotic fluid levels of phthalate monoesters in rats after the oral administration of di-(2-ethylhexyl) phthalate and di-n-butyl phthalate. Toxicology 2006;217:22-30.

35. Kavlock R, Boekelheide K, Chapin R, Cunningham M, Faustman E, Foster $\mathrm{P}$, et al. Phthalates expert panel report on the reproductive and developmental toxicity of di-n-octyl phthalate. Reprod Toxicol 2002;16:721-34.

36. Tabacova S, Balabaeva L, Little RE. Maternal exposure to exogenous nitrogen compounds and complications of pregnancy. Arch Environ Health 1997;52:341-7.

37. Gladen BC, Tabacova S, Baird DD, Little RE, Balabaeva L. Variability of lipid hydroperoxides in pregnant and nonpregnant women. Reprod Toxicol 1999;13:41-4.

38. Mein KM, Mortensen GK, Kaleva MM, Boisen KA, Damgaard IN, Chellakooty M, et al. Human breast milk contamination with phthalates and alterations of endogenous 
reproductive hormones in infants three months of age. Environ Health Perspect 2006;114:270-6.

39. Palanza P, Parmigiani S, vom Saal FS. Urinemarking and maternal aggression of wild female mice in relation to anogenital distance at birth. Physiol Behav 1995;58:827-35.

40. Hughes CL. Anogenital distance at birth as a predictor of volume of the sexually dimorphic nucleus of the preoptic area of the hypothalamus and pituitary responsiveness in castrated adult rats. Biol Reprod 1992;46:101-4.

41. Gallavan RH, Holson JF, Stump DG, Knapp JF, Reynolds VL. Interpreting the toxicologic significance of alterations in anogenital distance: potential for confounding effects of progeny body weights. Reprod Toxicol 1999;13: $383-90$.

42. Andrade AJ, Grande SW, Talsness CE, Grote K, Chahoud I. A dose-response study following in utero and lactational exposure to di-(2-ethylhexyl)-phthalate (DEHP): non-monotonic dose-response and low dose effects on rat brain aromatase activity. Toxicology 2006;27:185-92.

43. Swan SH. Environmental phthalate exposure in relation to reproductive outcomes and other health endpoints in humans. Environ Res 2008;108(2):174-84. DOI: 10.1016/j.envres.2008.08.007.

44. Bustamente-Montes LP, Hernandez-Valero MA, Garcia-Fabila M, Halley-Castillo E, Karam-Calderon MA, Borja-Aburto VH. Prenatal phthalate exposure and decrease in anogenital distance in Mexican male newborns. Epidemiol 2008;19(60):270-5.

45. Huang P-C, Kuo P-L, Chou Y-Y, Lin S-J, Lee C-C. Association between prenatal exposure to phthalates and the health of newborns. Environ International 2009;35:14-20.

46. Ge RS, Chen GR, Tanrikut C, Hardy MP. Phthalate ester toxicity in Leydig cells: developmental timing and dosage considerations. Reprod Toxicol 2007;23(3):366-73.

47. Borch J, Axelstad M, Vinggaard AM, Dalgaard M. Diisobutyl phthalate has comparable anti-androgenic effects to di-n-butyl phthalate in fetal rat testis. Toxicol Lett 2006;163(3):183-90.
48. Duty SM, Silva MJ, Barr DB, Brock JW, Ryan L, Chen Z, et al. Phthalate Exposure and Human Semen Parameters. Epidemiol 2003;14:269-77.

49. Jönsson AG, Richthoff J, Rylander L, Giwercman A, Lars H. Urinary phthalate metabolities and biomarkers of reproductive function in young men. Epidemiol 2005;16(4): 487-93.

50. Wirth JJ, Rossano MG, Potter R, Puscheck E, Daly DC, Paneth $\mathrm{N}$, et al. A pilot study associating urinary concentrations of phthalate metabolities and semen quality. Sys Biol Reprod Med 2008;54(3):143-54.

51. Pant N, Shukla M, Patel KD, Shukla Y, Mathur N, Gupta YK, Saxena DK. Correlation of phthalate exposures with semen quality. Toxicol App Pharmacology 2008;231:112-6.

52. Zhang Y, Zheng L, Chen B. Phthalate exposure and human semen quality in Shanghai: a cross-sectional study. Biomed Environ Sci 2006;19(3):205-9.

53. Hauser R, Meeker JD, Singh NP, Silva MJ, Ryan L, Duty S, et al. DNA damage in human sperm is related to urinary levels of phthalate monoester and oxidative metabolites. Hum Reprod 2007;22:688-95.

54. Duty SM, Singh NP, Silva MJ, Barr DB, Brock JW, Ryan L, et al. The relationship between environmental exposures to phthalates and DNA damage in human sperm using the neutral comet assay. Environ Health Perspect 2003;111:1164-9.

55. Brown JS Jr. Effects of bisphenol-A and other endocrine disruptors compared with abnormalities of schizophrenia: an endocrine-disruption theory of schizophrenia. Schizophr Bull 2009;35:256-78.

56. Masuo Y, Morita M, Oka S, Ishido M. Motor hyperactivity caused by a deficit in dopaminergic neurons and the effects of endocrine disruptors: A study inspired by the physiological roles of PACAP in the brain. Regul Pept 2004;15:225-34.

57. Engel SM, Zhu C, Berkowitz GS, Calafat AM, Silva MJ, Miodovnik A, Wolff MS. Prenatal phthalate exposure and performance on Neonatal Behavioral Assessment Scale in multiethnic birth cohort. NeuroToxicol 2009;30:522-8. 
58. Kim BN, Cho SC, Kim Y, Shin MS, Yoo HJ, Kim JW, et al. Phthalates exposure and attention-deficit/hyperactivity disorder in school-age children. Biol Psychiatry 2009;66(10):958-63.

59. Cho SC, Bhang SY, Hong YC, Shin MS, Kim BN, Kim JW. Relationship between environmental phthalate exposure and the intelligence of school-age children. Environ Health Perspect 2010;118(7):1027-32.

60. Engel SM, Miodovnik A, Canfield RL, Zhu C, Silva MJ, Calafat AM, et al. Prenatal phthalate exposure is associated with childhood behavior and executive functioning. Environ Health Perspect 2010;118(4):565-71.

61. Swan SH, Liu F, Kruse RL, Wang C, Redmon JB, Sparks A, et al. Prenatal phthalate exposure and reduced masculine play in boys. Int J Androl 2009;32:1-9.

62. Huang PC, Kuo PL, Guo YL, Liao PC, Lee CC.Associations between urinary phthalate monoesters and thyroid hormones in pregnant women. Hum Reprod 2007;22(10):2715-22.

63. Meeker JD, Calafat AM, Hauser R. Di(2-ethylhexyl) phthalate metabolites may alter thyroid hormone levels in men. Environ Health Perspect 2007;115(7):1029-34.

64. Boas M, Feldt-Rasmussen U, Skakkebaek NE, Main KM. Environmental chemicals and thyroid function. Eur J Endocrinol 2006;154:599-611.

65. Liwnicz BH, Liwnicz RG. On endocrine function. In: Kaplan LA, editor. Clinical Chemistry: Theory, Analysis and Correlation. 2nd ed. St. Lewis, MO: CV Mosby Company; 1989. p. 607-19.

66. Partsch CJ, Sippell WG. Pathogenesis and epidemiology of precocious puberty. Effects of exogenous oestrogens. Hum Reprod Update 2001;7:292-302.

67. Key TJ, Verkasalo PK, Banks E. Epidemiology of breast cancer. Lancet Oncol 2001;2:133-40.

68. Lopez-Carillo L, Hernandez-Ramirez RU, Calafat AM, Tores-Sanches L, Galvan-Portillo M, Needham LL, et al. Exposure to phthalates and breast cancer risk in Northen Mexico. Environ Health Perspect 2010;118(4):539-44.

69. Nydick M, Butos J, Dale JH, Rawson RW. Gynecomastia in adolescent boys. JAMA 1961;178:449-54.
70. Durmaz E, Özmert NE, Erkekoglu P, Giray B, Derman O, Hincal F, et al. Plasma Phthalate Levels in Pubertal Gynecomastia. Pediatrics 2010;125:122-9.

71. Colón I, Caro D, Bourdony CJ, Rosario O. Identification of phthalate esters in the serum of young Puerto Rican girls with premature breast development. Environ Health Perspect 2000;108:895-900.

72. Qiao L, Zheng L, Cai D. Study of the di-n-butyl phthalate and di-2-ethylhexyl-phthalate level of girls serum related with precocious puberty in Shanghai. Wei Shen Yan Jiu 2007;36(1):93-5 [in Chinese].

73. Lomenick JP, Calafat AM, Melguizo Castro MS, Mier R, Stenger P, Foster MB, et al. Phthalate exposure and precocious puberty in females. $J$ Pediatr 2010;156(2):221-5.

74. Brasche S, Bischof W. Daily time spent indoors in German homes - baseline data for the assessment of indoor exposure of German occupants. Int J Hyg Environ Health 2005;208(4):247-53.

75. Selgrade MK, Lemanske RF Jr, Gilmour MI, Neas LM, Ward MD, Henneberger PK, et al. Induction of asthma and the environment: what we know and need to know. Environ Health Perspect 2006;114:615-9.

76. Jaakkola JJ, Verkasalo PK, Jaakkola N. Plastic wall materials in the home and respiratory health in young children. Am J Pub Health 2000;90:797-9.

77. Jaakkola JJ, Parise H, Kislitsin V, Lebedeva NI, Spengler JD. Asthma, wheezing, and allergies in Russian schoolchildren in relation to new surface materials in the home. Am J Pub Health 2004;94:560-2.

78. Larsson M, Hagerhed-Engman L, Kolarik B, James P, Lundin F, Sundell J, et al. PVC flooring and its association with incident asthma in Swedish children. Indoor Air 2010;20: 494-501.

79. Dirven HA, van den Broek PH, Arends AM, Nordkamp HH, de Lepper AJ, Henderson PT, et al. Metabolites of the plasticizer di(2-ethylhexyl) phthalate in urine samples of workers in polyvinyl chloride processing industries. Int Arch Occup Environ Health 1993;64:549-54. 
80. Koch HM, Bolt HM. Angerer J. Di(2-ethylhexyl)phthalate (DEHP) metabolites in human urine and serum after a single oral dose of deuterium-labeled DEHP. Arch Toxicol 2004;78:123-30.

81. Hauser R, Meeker JD, Park S, Silva MJ, Calafat AM. Temporal variability of urinary phthalate metabolite levels in men of reproductive age. Environ Health Perspect 2004;112:1734-40.

82. Silva MJ, Reidy JA, Herbert AR, Preau Jr JL, Needham LL, Calafat AM. Detection of phthalate metabolites in human amniotic fluid. Bull Environ Contam Toxicol 2004;72:1226-31.

83. Teitelbaum SL, Britton JA, Calafat AM, Ye X, Silva MJ, Reidy JA, et al. Temporal variability in urinary concentrations of phthalate metabolites, phytoestrogens and phenols among minority children in the United States. Environ Res 2008;106(2):257-69.

84. Moore KL, Persaued TV. The developing human: clinically oriented embryology. Philadelphia: W.B. Saunders; 1998. p. 157-65.

85. James DK, Steer PJ, Weiner CP, Gonik B. High risk pregnancy: management options. Third Edition. Philadelphia, PA: Elsevier-Saunders; 2005.
86. Lewis ML,Worobey JW, Ramsay DS, McCormack MK. Prenatal exposure to heavy metals: effect on childhood cognitive skills and health status. Pediatrics 1992;89:1010-5.

87. Longnecker MP, Gladen BC, Cupul-Uicab LA, RomanoRiquer SP,Weber JP, Chapin RE, et al. In utero exposure to the antiandrogen 1,1-dichloro-2,2-bis(p-chlorophenyl)ethylene $(D D E)$ in relation to anogenital distance in male newborns from Chiapas, Mexico. Am J Epidemiol 2007;165:1015-22.

88. Dallaire F, Dewailly E, Muckle G, Ayotte P. Time trends of persistent organic pollutants and heavy metals in umbilical cord blood of Inuit infants born in Nunavik (Québec, Canada) between 1994 and 2001. Environ Health Perspect 2003;111:1660-4.

89. Wang SL, Su PH, Jong SB, Guo YL, Chou WL, Päpke O. In utero exposure to dioxins and polychlorinated biphenyls and its relations to thyroid function and growth hormone in newborns. Environ Health Perspect 2005;113:1645-50.

90. Engman LH, Bornehag, CG, Sundell J. How valid are parents questionnaire responses regarding building characteristics, mouldy odour, and signs of moisture problems in Swedish homes? Scand J Publ Health 2007;35:125-32.

This work is available in Open Access model and licensed under a Creative Commons Attribution-NonCommercial 3.0 Poland License - http://creativecommons.org/ licenses/by-nc/3.0/pl/deed.en. 